\title{
Agrin Downregulation Induced by Nerve Injury Contributes to Neuropathic Pain
}

\author{
Jian-Guo Cui and Nicolas G. Bazan \\ Neuroscience Center of Excellence, Louisiana State University Health Sciences Center, School of Medicine, New Orleans, Louisiana 70112
}

The elusiveness of neuropathic pain mechanisms is a major impediment in developing effective clinical treatments. Here we show that peripheral nerve injury decreased agrin expression in the ipsilateral spinal dorsal horn of rats displaying tactile allodynia. SCP1, an acetaminophen analog, suppressed allodynia and promoted agrin upregulation. Preemptive treatment with SCP1 also upregulated agrin, thereby preventing neuropathic pain development. Expression of $50 \mathrm{kDa}$ agrin delivered by adeno-associated virus into the dorsal horn also suppressed allodynia and hyperalgesia. Allodynia suppression was a consequence of serine residue 896/897 phosphorylation of NMDA receptor NR1 subunits in the GABA interneurons of the dorsal horn. Agrin silencing by small interference RNA, administered with either AAV-Ag50 vector or SCP1, blocked allodynia suppression, agrin upregulation, and NR1 phosphorylation. In conclusion, $50 \mathrm{kDa}$ agrin modulates neuropathic pain through NR1 phosphorylation in GABA neurons. This mechanism may open new approaches for treating not only neuropathic pain, but also epilepsy, tremors, and spasticity.

\section{Introduction}

Neuropathic pain is defined according to the International Association for the Study of Pain as "pain initiated or caused by primary lesion or dysfunction in the nervous system." As a result, hyperalgesia (pain resulting from overresponse to a noxious stimulus) and/or allodynia (pain evoked by a non-noxious stimulus) take place. The causes of neuropathic pain include diabetes, infections (viral or bacterial), trauma, neurotoxins, neurodegenerations, and cancer (Santiago-Figueroa and Kuffler, 2009). It is estimated that $1.5-3.0 \%$ of the world's population is affected by neuropathic pain. As a major consequence of neuropathic pain, a patient's quality of life is deeply affected. Therapy is often ineffective due to a lack of understanding of the mechanisms involved in neuropathic pain (O'Connor and Dworkin, 2009). Our finding that agrin is a major mediator of pain in the dorsal horn (DH) of the rat spinal cord offers a new explanation for specific molecular mechanisms that lead to neuropathic pain.

Agrin, a single-gene-encoded heparan sulfate proteoglycan of $\sim 220 \mathrm{kDa}$, participates in nerve-muscle synaptic biogenesis through induction of acetylcholine receptor aggregation at postsynaptic sites, thereby generating a junction (Magill et al., 1987; Rupp et al., 1992). The word “agrin” (Greek agreirein) de-

Received Aug. 23, 2010; revised Sept. 14, 2010; accepted Sept. 17, 2010.

This work was supported by a Louisiana State University Health Sciences Center Translational Research Initiative Grant and the Neurobiotechnology Program of Louisiana. We thank Dr. Ping Zhang and Constance Porretta for their assistance with GAD65 cell sorting and Ryan Labadens for his editorial assistance.

N.G.B. is the inventor of the SCP technologies and compositional matter, and the Louisiana State University Health Sciences Center is the assignee of the SCP1 patents licensed to St. Charles Pharmaceuticals, Inc. N.G.B. was involved in the inception of St. Charles Pharmaceuticals, Inc. (2000) and is listed on the Board of Directors; however, he is not presently a consultant for this company.

Correspondence should be addressed to either Nicolas G. Bazan or Jian-Guo Cui, Neuroscience Center of Excellence, Louisiana State University Health Sciences Center, 2020 Gravier Street, Suite D, New Orleans, LA 70112-2272. E-mail: nbazan@|suhsc.edu or jcui@|suhsc.edu.

DOI:10.1523/JNEUROSCI.4418-10.2010

Copyright $\odot 2010$ the authors $\quad 0270-6474 / 10 / 3015286-12 \$ 15.00 / 0$ notes its ability to bring diverse molecules together to perform specific functions. Alternative messenger RNA splicing produces agrin isoforms in different organs and cellular locations (Ruegg et al., 1992; Hoch et al., 1993). In the CNS, agrin induces synapse formation and axon growth, although its physiological significance is not completely understood (Mantych and Ferreira, 2001; Smith and Hilgenberg, 2002). Our observations suggest that agrin is involved in neuropathic pain modulation.

The NMDA receptor, a main player in pain modulation, is expressed in neurons, glial cells, and GABAergic neurons (Schipke et al., 2001; Xi et al., 2009), and has broad biological functions. So far, no data are available detailing the interactions between agrin and the NMDA receptor. Here, we demonstrate that agrin modulates neuropathic pain in the lumbar $\mathrm{DH}$ through NMDA receptor NR1 subunits.

\section{Materials and Methods}

Animal studies were performed according to National Institutes of Health guidelines and protocols were approved by the Louisiana State University Health Sciences Center Institutional Animal Care and Use Committee. Sprague Dawley rats (male, 250-280 g) were housed in plastic cages with soft bedding, ad libitum food/water access, and a 12/12 h day/night cycle for $7 \mathrm{~d}$ before the sciatic nerve surgery and after.

\section{Bennett model}

The left sciatic nerve was exposed and freed with sharpened scissors at the midthigh level. Four ligatures were placed loosely around the sciatic nerve with 4-0 chromic catgut, which compressed the nerve but preserved epineural blood circulation (Bennett and Xie, 1988).

\section{Gazelius model}

The left sciatic nerve was exposed at midthigh level. A green laser beam with a wavelength of $532 \mathrm{~nm}$ ( $4.5 \mathrm{~mW}$ output) was focused $0.5 \mathrm{~mm}$ above the nerve to irradiate the sciatic nerve for $20 \mathrm{~min}$ immediately following intravenous erythroin-B injection (Gazelius et al., 1996) $(32.5 \mathrm{mg} / \mathrm{kg}$, Sigma). 


\section{Behavioral studies}

In a quiet room with daylight-like illumination, animals were adapted to the experimental environment for 15 min 3 times before collecting data. The data were collected between 9:30 A.M. and 3:30 P.M.

Mechanical sensitivity test. In a glass chamber $(20 \times 20 \mathrm{~cm})$ with a mesh net floor, animals were subjected to the tactile allodynia test in which an innocuous touch stimulus may induce a brief paw withdrawal. A series of von Frey filaments from 0.01 to $26 \mathrm{~g}$ (Stoelting) was applied to the midpaw of rats, starting from $1 \mathrm{~g}$, and increasing or decreasing. If a filament induced a withdrawal of a paw 3 times out of 5 stimuli, the value was recorded as the animal's withdrawal threshold. Allodynia was considered present when a withdrawal threshold was evoked by a filament corresponding to $8 \mathrm{~g}$ or less. Nonallodynia was defined as the withdrawal threshold being $20 \mathrm{~g}$ or higher. When a von Frey filament was applied to lower trunk and leg skin of a rat with the same methods, and induced quick avoiding and vocalization, the rat was classified as allodynic.

Thermal hyperalgesia test (Hargreaves). The light beam was focused on a paw plantar and induced paw withdrawal when the temperature generated by the light reached paw withdrawal threshold. The temperature of the floor was set at $28^{\circ} \mathrm{C}$, and the intensity of the light beam was set at $35 \%$ of the light source's power (IITC LifeSci). The paw withdrawal latency (in seconds) was defined as the time lapse between the stronger light onto the paw and the paw withdrawal. Two consecutive tests were averaged to establish the threshold using 5 min intervals. If a latency value of an injured paw was 30\% lower than that of preinjury baseline and/or sham rats, the animal was considered to be thermally hyperalgesic.

\section{Intrathecal catheter installation}

A PE10 catheter was introduced into the spinal canal (subarachnoid space) via a $21 \mathrm{G}$ cannula between the L5 and L6 vertebra and advanced to the lumbar enlargement in rats. The proximal part was tunneled under the skin and led out onto the upper dorsal region. The location of the catheter was verified by the injection of $6 \mu \mathrm{l}(50 \mathrm{mg} / \mathrm{ml})$ xylocaine, such that a transient, flaccid paralysis of the legs was produced. A successful intrathecal catheter installation is indicated by the following: a brisk tail flick when a G21 needle punctures between the L5 and L6 vertebra; clear CSF drops flowing out the catheter; and a transient paralysis of the legs produced by xylocaine. SCP1, $n$-[ $\alpha$-benzisothiazol-3(2ho-ona-1,1dioxide-2yl)-acetyl]-p-aminophenol, is a derivative of acetaminophen (APAP) by chemically linking a sodium saccharin to its C4 bond. SCP1 (100 nmol, when given intrathecally) displays better suppressive effects on neuropathic pain with limited liver or kidney toxicity. SCP1 also shows inhibitory effects on voltage-gated calcium current in dorsal root ganglion (DRG) neurons. SCP1 was dissolved in 45\% 2-hydroxypropyl$\alpha$-cyclodextrin with saline at a final concentration of $10 \mathrm{~mm}$. A maximum $10 \mu \mathrm{l}$ volume injection was performed once per rat.

\section{RNA extraction}

The rats were deeply anesthetized with halothane and decapitated. Spinal cord L3 -5 was quickly removed and put immediately into TRIzol ( $2 \mathrm{ml})$. Following the TRIzol protocol, RNA was extracted and tested with an RNA gene chip (Agilent 2100 Bioanalyzer) or a biophotometer (Eppendorf) for concentration and quality. Only the RNA with $\mathrm{A}_{260 / 280}>2.0$ and/or Ratio ${ }_{18 \mathrm{~S} / 28 \mathrm{~S}}>1.4$ was used for the experiments. The RNA samples were stored at $-80^{\circ} \mathrm{C}$.

\section{One-step RT-PCR}

Gene expression for agrin was analyzed by RT-PCR from RNA samples of L3-5 spinal cord segments at time points $2 \mathrm{~h}, 1 \mathrm{~d}, 3 \mathrm{~d}$, and $7 \mathrm{~d}$ after surgery or 1,2 , and $24 \mathrm{~h}$ after drug treatment. A total volume of $50 \mu \mathrm{l}$ was used for the reaction of reverse-transcription polymerase with $1 \mu \mathrm{g}$ of RNA, $25 \mu$ l of buffer, $1 \mu \mathrm{l}$ of RT/Platinum Taq Mix (SuperScript, Invitrogen), $2 \mu \mathrm{l}$ of $\mathrm{MgSO}_{4}(50 \mathrm{~mm})$, and $2 \mu \mathrm{l}$ of primers $(10 \mu \mathrm{M})$. The reaction was run for $22 \mathrm{~min}$ at $48^{\circ} \mathrm{C}, 2 \mathrm{~min}$ at $95^{\circ} \mathrm{C}$, followed by 36 cycles of $95^{\circ} \mathrm{C}$ for $30 \mathrm{~s}, 60^{\circ} \mathrm{C}$ for $30 \mathrm{~s}$, and $72^{\circ} \mathrm{C}$ for $1 \mathrm{~min}$. The forward primer for the C-terminal half was $5^{\prime}$-TCAGGAGCAAAGAGCCCATAGC- $3^{\prime}$ and the reverse was 5'-ATGTAGGTCCGCCCATCAAAGG-3' (Bacman 2.0). The forward primer for the N-terminal half of agrin was $5^{\prime}$ -
TGGCAGTGACGGTGTTGACTAC-3' and the reverse was 5'-CACGGCGGGACAGGCATAC-3' (Bacman 2.0).

\section{Probe synthesis and gene-chip hybridization}

RNA $(8.5 \mu \mathrm{g})$ from each sample (three rats for each group) was used for first- and second-strand cDNA synthesis with a double-strand cDNA kit (Invitrogen). The double cDNAs were converted to cRNAs using an Enzo Bioarray High-Yield RNA transcript labeling kit. The cRNAs were biotinylated and segmented into about $200-400 \mathrm{nt}$ probes. The probes were hybridized against U34A gene-chip DNA arrays. Expressed sequence tag clusters were analyzed by UniGene database Build 74 (Affymetrix).

\section{Protein extraction}

The rats were deeply anesthetized with halothane and decapitated. Spinal cord L3-5 was quickly removed and put immediately into tissue lysis buffer ( $1 \mathrm{ml}$, Sigma), along with protein enzyme inhibitors (1:100, Halt, Pierce Biotechnology). When the samples were used for p-NR1 detection, phosphase inhibitor cocktail (Sigma) was added to the lysis buffer. The tissue was homogenized for $2 \mathrm{~min}$ and incubated on ice for $45 \mathrm{~min}$. Then the sample was centrifuged at $10,000 \times g$ for $30 \mathrm{~min}$ at $4^{\circ} \mathrm{C}$. The supernatant was transferred to a new tube and centrifuged again for further clarification. The concentration of the protein was determined by Agilent protein chip (Agilent 2100 Bioanalyzer) and Bedford method (reagents from Bio-Rad).

\section{Western blot}

Protein samples $(20 \mu \mathrm{g})$ from L3-5 spinal cord segments at days 1, 3, and 7 after surgery were loaded on $4-15 \%$ acrylamide tris-glycine SDS gels and electrophoresed in a cell (Bio-Rad) for $1 \mathrm{~h}$. A Hybond-P polyvinylidene difluoride membrane was used for transferring the protein in a transfer cell (Bio-Rad) for $1 \mathrm{~h}$. Then the membrane was probed with agrin or p-NR1 antibody at $4^{\circ} \mathrm{C}$ overnight with continuous shaking. The membrane was then incubated with a secondary antibody conjugated to Alexa Fluor680 for 1 h. $\beta$-Actin antibody was labeled as a sample loading control and intensity analysis control. Three washes were performed between steps. The membrane was scanned with an Odyssey (LI-COR) scanner and analyzed by Odyssey software. The band intensity for a specific antibody was compared to the percentage from the sample's $\beta$-actin band. The percentage was defined as relative intensity for protein expression analysis. The antibodies and their concentrations used were as follows: monoclonal agrin (Agr510 and Agr520, 1:5000, Stressgen); polyclonal p-NR1 antibody (1:1000), p-NR2A (1:1000), and p-NR2B (1:1000) (all from Millipore Bioscience Research Reagents); goat anti-mouse or anti-rabbit secondary antibody conjugated to Alexa Fluor680 (1:5000, Invitrogen); and $\beta$-actin antibody (1:5000, Sigma).

\section{Immunohistochemistry}

At $7 \mathrm{~d}$ after surgery or $2 \mathrm{~d}$ after treatment, the animals were deeply anesthetized with isoflurane and perfused via the left ventricle with 250 $\mathrm{ml}$ of $4 \%$ paraformaldehyde. The L $4-5$ spinal cords for each treated rat were dissected out and cut into $20 \mu \mathrm{m}$ sections with a cryostat (Leica). The sections were mounted on a slide and stored at $-80^{\circ} \mathrm{C}$. When processed for staining, the sections were air dried for $45 \mathrm{~min}$, followed by a PBS wash for $10 \mathrm{~min}$, three times. The sections for agrin, $\mathrm{p}-\mathrm{NR} 1$, or the GABA antibody were processed using standard protocols. An Axioplan2 fluorescence microscope (Zeiss) with deconvolution function and LSM50 confocal microscope were used to record histological images. The antibodies used were as follows: agrin (Agr510 and Agr530, 1:8000, Stressgen); GAP43 (1:1000, Santa Cruz Biotechnology); GFAP (1:1500, Sigma); p-NR1 (1:1000), GAD65/67 (1:1500), and GABA (1:800) (all from Millipore Bioscience Research Reagents); $\beta$-actin (1:5000, Sigma); FITC (1:1000, BD Biosciences); and Cy3 (1:1500, GE Healthcare).

Fluorescent particles corresponding to protein sizes were measured by ImagePro Plus5.0. If an agrin fluorescent particle was larger than $1 \mu \mathrm{m}$, then the particle was classified as positive. The fluorescent intensity display range for agrin and p-NR1 was set from 150 to 1250 . The particles in the laminae I-IV were counted and analyzed. p-NR1 fluorescent particles were defined as positive if a particle was larger than $3 \mu \mathrm{m}$; the number of positive particles was averaged from two miscopy-sight fields on a slide. For each staining, 6-8 nonadjacent sections from a rat were counted. A 
standard slide was used for background correction before each image was taken. Controls for each antibody staining included the following: (1) no primary antibody staining, (2) antigen absorption by peptide, and (3) positive and negative tissue staining.

\section{Immunoprecipitation}

Fifty microliters of dynamic beads (Invitrogen) were incubated with agrin antibody of $2-4 \mu \mathrm{g}$ for $45 \mathrm{~min}$. The supernatant was discarded and beads were washed with binding buffer. Sample proteins of $200-400 \mu \mathrm{g}$ were added and incubated with the beads for $4 \mathrm{~h}$ at $4^{\circ} \mathrm{C}$. The complex was washed 3 times and eluted with the SDS sample buffer at $95^{\circ} \mathrm{C}$ for $10 \mathrm{~min}$. The samples were subjected to Western blot for p-NR1.

\section{Spinal cord tissue culture}

Fresh lumbar spinal cord from 7-10 d postnatal rats was cut into $1 \mathrm{~mm}$ sections with a sharp blade under sterile conditions and maintained in culture in 12-well plates with DMEM and 10\% FBS. After $1 \mathrm{~d}, 100 \mu \mathrm{M}$ NMDA or $100 \mu \mathrm{m}$ NMDA plus Substance P (10 nM) was added to six wells each. Another six wells were used as controls. The culture was maintained for $6 \mathrm{~h}$ and $1 \mathrm{~d}$, and the tissue was subjected to RNA and protein extraction as well as RT-PCR and Western blot to examine alterations of the agrin gene and protein, as described above.

\section{$A A V$-agrin construct}

AAV backbone was designed to contain a CMV promoter, a T7 promoter, a multiple cloning site, a $m y c$ and a His epitope, and a BGH poly A. An agrin sequence (NM-175754) from 4557 to 6021 or from 5297 to 6021 was inserted into the backbone. Agrin genes (NM_175754; Ag50: nucleotides 4557-6021) with CGAGCTGACCAATGAGATCCCAGC insert at the $\mathrm{Z}$ site between $5537(G)$ and $5538(T)$ and GAAATCCCGCAA insert at the $\mathrm{Y}$ site between $5126(\mathrm{C})$ and 5127 (G, after insert $\mathrm{G}$ becomes 5139) were installed into AAV2 by BamHI and NotI. Markers of $m y c$ and His were tagged at the end of the agrin sequence. AAV2-Ag25 (Ag25: nucleotides 5297-6021) was with CGAGCTGACCAATGAGATCCCAGC insert at the $\mathrm{Z}$ site. After sequencing confirmation, the AAV2-Ag viruses were used for infecting HEK293 cells. The AAV2-Ag viral particles were harvested and purified. The titer of the particles was determined by realtime PCR.

\section{Intraneural injection of $A A V$-Ag vectors}

The vertebral column of the rats was stabilized by two clamps holding the $\mathrm{T} 11$ and L2 process on a stereotaxic frame, leaving the chest free to move. A semilaminectomy was performed at the left conjunction of the T13 and L1 vertebrae. A modified Hamilton G33 syringe with a finer, shorter tip (length: $0.18 \mathrm{~mm}$; OD: $0.18 \mathrm{~mm}$ ) was used for the vector delivery. The needle was inserted into the left $\mathrm{L} 4-5 \mathrm{DH}$ along with the root entry at a depth of $220-250 \mu \mathrm{m}$ with a micromanipulator. In this way, $5 \times 10^{10}$ genome copies (GC) of each AAV2 vector $(3 \mu \mathrm{l})$ were delivered at 0.4 $\mu \mathrm{l} / \mathrm{min}$. AAV-GFP vectors $\left(3 \mu \mathrm{l}, 5 \times 10^{8} \mathrm{GC}\right)$ also were injected into the superficial lamina of $\mathrm{DH}$ as a visible protein expression control at $48 \mathrm{~h}$ after injection.

\section{Dorsal spinal GABA cell sorting}

Dorsal lumbar spinal cells from 7-10 d postnatal rats were dissected and digested by $0.125 \%$ trypsin and $0.125 \%$ collagenase for $20 \mathrm{~min}$. After cells were suspended, GAD65 antibody ( $1 \mu \mathrm{g}$ for 1 million cells; Abcam) was incubated with the cells for $45 \mathrm{~min}$. Then, PE (phycoerythrin) secondary antibody ( $1 \mu \mathrm{g}$ for 1 million cells; Abcam) was incubated with the cells for $30 \mathrm{~min}$. The cells were washed with PBS between steps. BD Biosciences FACSAria flow cytometer (Becton Dickinson) was used to aseptically sort GAD65-PE-positive cells (488 nm excitation/585 nm emission). The sorted cells were cultured on a 16 -well chamber slide (20,000 cells per well) in DMEM/F12 medium supplement with $50 \% \mathrm{~N}_{2}$ and $50 \% \mathrm{~B} 27$. After $4 \mathrm{~d}$ incubation at $37^{\circ} \mathrm{C}$, purified $50 \mathrm{kDa}$ agrin protein at concentrations of $0.02,0.2$, and $2 \mathrm{ng} / \mathrm{ml}$ was applied to the culture. After 15 and 30 min of incubation, cells were fixed and stained for $\mathrm{p}-\mathrm{NR} 1$ and GABA antibodies and analyzed under a microscope.

\section{$50 \mathrm{kDa}$ agrin purification}

The $50 \mathrm{kDa}$ agrin gene was inserted into a pSecTag 2B vector with $H$ is tag by BamHI and NotI. After the plasmid was sequenced and amplified, it was used to transfect HEK293 cells with Lipofectamine LTX (Invitrogen) in $15 \mathrm{~cm}$ dishes. After $48 \mathrm{~h}$, the cells were collected with trypsin and purified by ProBond column, which has the high affinity and selectivity of 6x His-tagged proteins. A hybrid method of denaturing conditions and native conditions was used for purifying the $50 \mathrm{kDa}$ agrin proteins. After elution with a native elution buffer, agrin was analyzed by Western blot. The protein activity efficiency was compared to the $50 \mathrm{kDa}$ agrin secreted into the culture medium by Ag50-vector-transfected HEK293 cells for induction of NR1 phosphorylation.

\section{Agrin RNA interference development and intrathecal injection} Agrin siRNA was designed and produced according to the Ambion protocol. Beginning with the AUG start codon of agrin mRNA, we searched for AA dinucleotide sequences and recorded each AA and the $3^{\prime}$ adjacent $19 \mathrm{nt}$ as siRNA target sites. Also, a negative-control siRNA, designed by computer and tested without a blocking effect on any mRNA, was used for the experiments. The two sets of siRNAs were used in the experiments for the $\mathrm{N}$-terminal half and for the C-terminal half of agrin mRNA, respectively: sense strand RNAi: CCUAGUGUUGAGGAUCCAGtt; antisense strand RNAi: CUGGAUCCUCAACACUAGGtt; and sense strand RNAi: GCCCUCAAAGUCCUGUGAUtt; antisense strand RNAi: AUCACAGGACUUUGAGGGCtt.

In rats with tactile allodynia, intrathecal catheters (PE 10) were installed and linked to an osmotic pump (Alzet), which was in a $37^{\circ} \mathrm{C}$ water bath or was implanted subcutaneously. Following a bolus injection of SCP1 (100 nmol, $10 \mu \mathrm{l}$ ), agrin siRNA (100 nM, containing $0.2 \%$ lipofectamine) was intrathecally administered continuously by the pump at a rate of $5 \mu \mathrm{l} / \mathrm{h}$ for $4 \mathrm{~h}$. The animals were subjected to von Frey filament test every $15 \mathrm{~min}$ for $4 \mathrm{~h}$ to determine whether the effects of SCP1 on allodynia suppression were blocked by agrin siRNA. A control siRNA (nonfunctional siRNA) was used in the same way. The paw withdrawal threshold and/or latency were analyzed for agrin effects. Immediately after behavioral experiments, the animals were subjected to protein extraction of the lumbar spinal cord and Western blot analysis, mRNA analysis, or immunohistochemistry analysis.

\section{Statistical analysis}

Changes of the paw withdrawal thresholds and paw withdrawal latency, before and after nerve injury or treatments with drug and vector in the same rat, were analyzed by one-way ANOVA, followed by the nonparametric Wilcoxon signed-rank test. Comparisons between different groups or different treatments were subjected to one-way ANOVA, followed by the Mann-Whitney test. Values of $p<0.05$ were considered significant. Data were presented as mean \pm SEM.

\section{Results}

\section{Agrin expression decreases after nerve injury in neuropathic rats}

RNA/DNA-wide array assays (U34A chip) showed that agrin expression decreased in the lumbar spinal cord of Bennett model rats [chronic constrictive injury (CCI) to the sciatic nerve] (Bennett and Xie, 1988). A 50\% decline in agrin was observed at day 7 after injury, correlating with neuropathic pain development (Fig. $1 A$ ). Moreover, by amplifying exons $21-24$ of agrin with RTPCR, we demonstrated that agrin expression decreased in allodynic rats (Fig. $1 B, D$ ). Since the agrin gene can be spliced into many isoform protein fragments (Bowe and Fallon, 1995; Hoover et al., 2003) and there are no detailed reports concerning agrin expression in the adult rat spinal cord, we examined agrin proteins from the L3-5 spinal cords using Western blot with agrin antibodies Agr510 (mapping the second laminin domain) and Agr520 (detecting inserts at the $\mathrm{Z}$ site). Both antibodies displayed approximately $50 \mathrm{kDa}$ and $25 \mathrm{kDa}$ agrin bands, suggesting that the two agrin isoforms expressed in the rat spinal cord contain the laminin domain and the Z-site inserts.

For the $25 \mathrm{kDa}$ and $50 \mathrm{kDa}$ bands, allodynic rats displayed a significant decrease at days 3 and 7 after CCI (Fig. 1C,E). The 
A

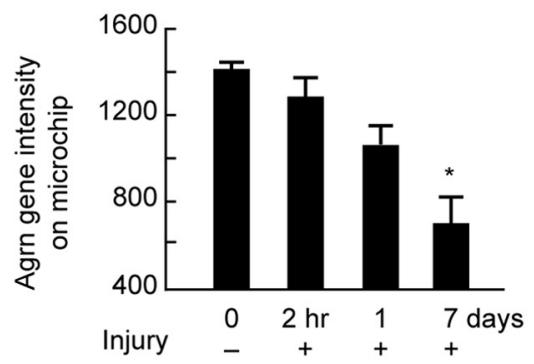

B

C

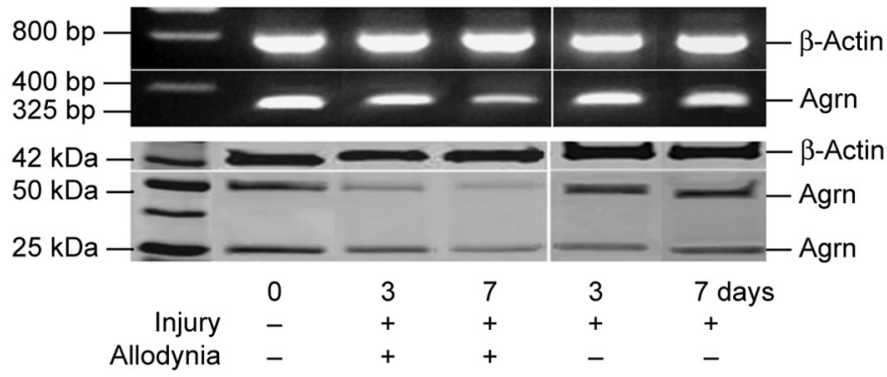

D

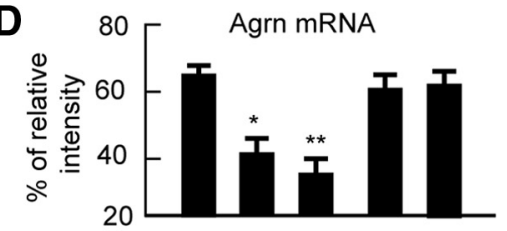

E

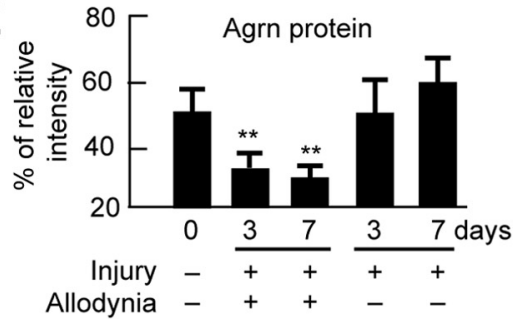

$\mathbf{F}$

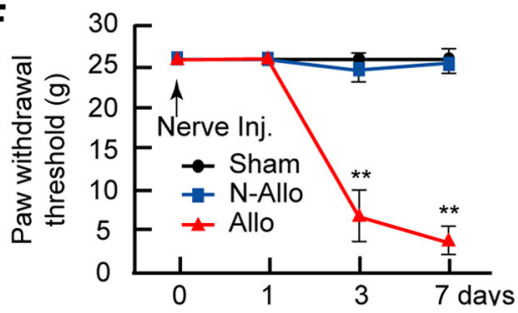

G

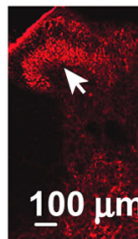

I

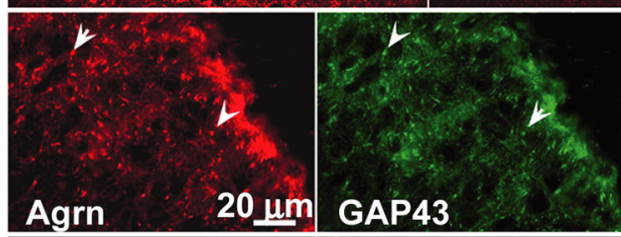

$\mathbf{K}$

\section{DAPI}

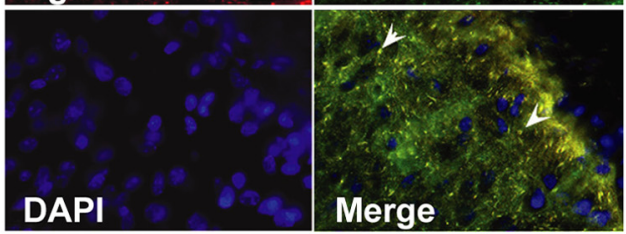

$\mathbf{K}$

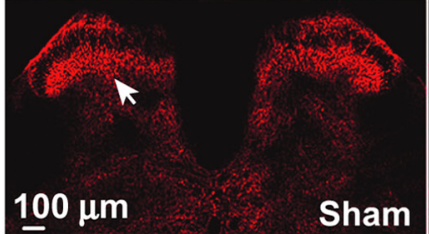

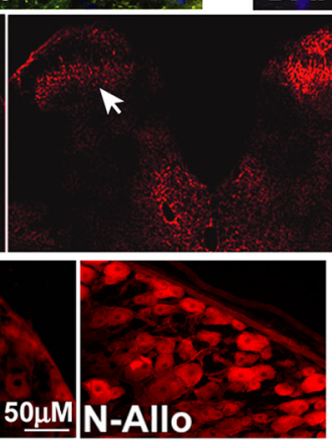

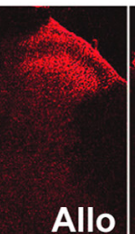

Allo
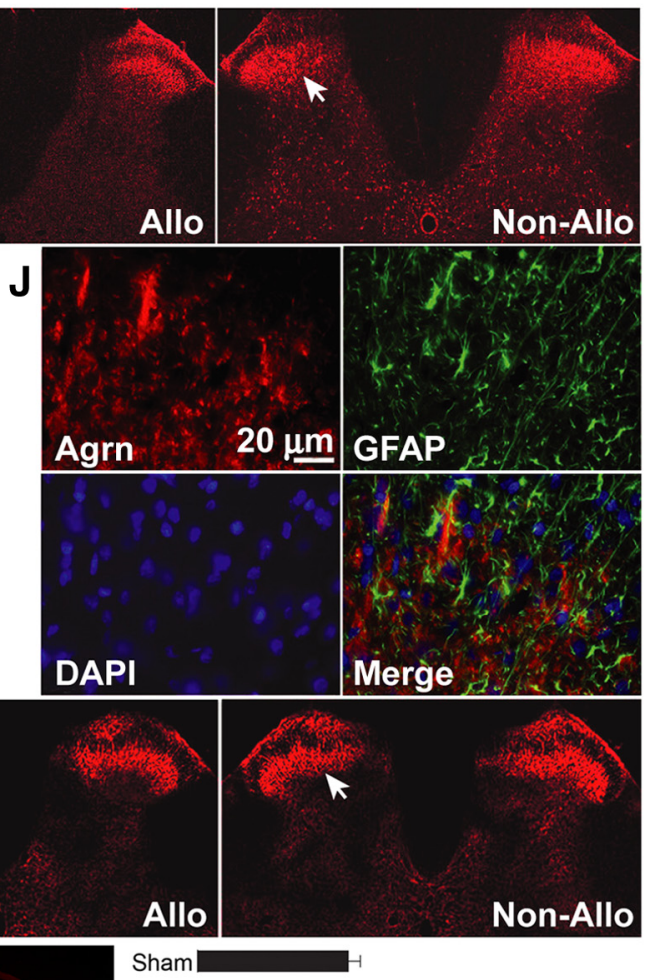

Allo 1 **

N-Allo

$$
\begin{array}{cc}
0 & 1000 \\
\text { Agrn Fluor Particles }
\end{array}
$$

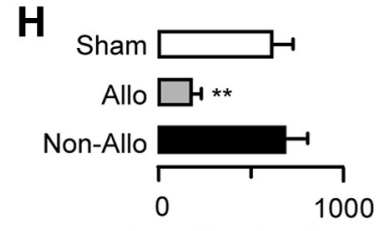

Agrn Fluor Particles

Figure 1. Agrin expression in the spinal cord following peripheral nerve injury. A, Agrin gene expression in L3-5 spinal cords from CCl rats measured by gene chip (U34A). In CCI rats, agrin mRNA began to decrease at day 3 after $\mathrm{CCl}$ and was decreased $50 \%$ at day 7 after $\mathrm{CCl}$, compared to that in sham rats (at day 7 after injury, $n=6,{ }^{*} p<0.05$; one-way ANOVA, followed by Mann-Whitney test; data are presented as mean \pm SEM). $B$, RT-PCR confirms C-terminal agrin mRNA was downregulated in allodynic rats after CCl using primers targeting exons 21-24, while no changes were observed in nonallodynic rats. C, Western blot shows that both 25 and $50 \mathrm{kDa}$ agrin proteins were markedly decreased in allodynic rats at days 3 and 7 after injury, while no agrin decrease was observed in nonallodynic rats. D, Relative intensity of agrin mRNA bands was decreased from $65 \%$ to $40 \%$ and $35 \%$ in allodynic rats at days 3 and 7 after CCl, respectively, in comparison with injured, nonallodynic rats and sham rats $\left(n=10\right.$ rats, each group. $\left.{ }^{*} p<0.05 ;{ }^{* *} p<0.01\right)$. $E$, Relative intensity of agrin protein bands was decreased from $52 \%$ to $33 \%$ and $28 \%$ in allodynic rats at days 3 and 7 after injury, respectively, in comparison with nonallodynic rats and sham rats $\left(n=12\right.$ rats; ${ }^{* *} p<0.01$; one-way ANOVA, followed by the Mann-Whitney test). $\boldsymbol{F}$, Average paw withdrawal threshold decreased significantly in allodynic group at 3 and $7 \mathrm{~d}$ after injury. The threshold decrease corresponds to agrin mRNA and protein decline. However, neither paw withdrawal threshold, nor agrin mRNA and protein decreased in nonallodynic group. There is a significant difference for paw withdrawal threshold between allodynic and nonallodynic, (Figure legend continues.) 
agrin decrease corresponds to the decline of paw withdrawal threshold (Fig. $1 F$ ) in behavioral tests. To test whether the $50 \mathrm{kDa}$ band is a dimer of the $25 \mathrm{kDa}$ protein, we used $2 \times$ TG SDS to break the S-bonds. The $50 \mathrm{kDa}$ agrin band remained unchanged. In nerve-injured rats, only animals displaying downregulation of $25 \mathrm{kDa}$ and $50 \mathrm{kDa}$ agrin developed tactile allodynia, indicated by an abnormally low paw withdrawal threshold. These results support the view that agrin downregulation is only associated with neuropathic pain development.

Agrin immunoreactivity was symmetrical (Fig. 1G) and mostly concentrated on laminae I-I-II in sham and nonallodynic rats. In allodynic rats, the immunoreactivity almost disappeared in the DH ipsilateral to the injury (Fig. $1 G$ ). There was a significant difference in the number of fluorescent particles between sham, nonallodynic, and allodynic rats (Fig. $1 H$ ). Western blot and immunostaining showed that agrin decreased only in allodynic rats. To define the cellular location of agrin in the $\mathrm{DH}$, double staining with antibodies for agrin and growth-associated protein 43 (GAP43) or glial fibrillary acidic protein (GFAP, a glial marker) was performed. GAP43 is a neuronal marker localized mainly on the presynaptic membrane (Skene et al., 1986; Gorgels et al., 1989). Our results revealed that agrin was colocalized with GAP43 in the DH (Fig. $1 I$ ), but not with GFAP (Fig. $1 J$ ), suggesting that agrin is in DH neurons and is mainly located on the presynaptic terminals. This notion is further supported by the fact that agrin was decreased in the DRGs of allodynic rats (Fig. $1 M$ ).

Although agrin was decreased in allodynic CCI rats (Fig. $1 \mathrm{~A}-$ $E, G)$, the question remains as to whether the decrease correlates to peripheral nerve injury. Therefore, we examined agrin changes at day 7 after injury in Gazelius model rats, which had a photochemical lesion made to the sciatic nerve (PCI) (Gazelius et al., 1996; Erichsen et al., 2003). In this model, agrin immunoreactivity decreased only in the DH of allodynic rats (Fig. $1 K, L$ ) in a pattern similar to the CCI model, implying that the agrin decrease correlated with the nerve-injury-induced allodynia. This is further supported by the fact that agrin was restored to preinjury levels in the $\mathrm{DH}$ when neuropathic pain was resolved in the CCI and PCI models (supplemental Fig. S1, available at www.jneurosci.org as supplemental material).

$\leftarrow$

(Figure legend continued.) sham-operated rats $\left(n=8\right.$ rats; ${ }^{* *} p<0.01$; one-way ANOVA, followed by the Mann-Whitney test). $\mathbf{G}$, Agrin immunoreactivity almost disappeared in laminae I-III of the DH ipsilateral to the injury in allodynic rats (CCl, arrow), while the immunoreactivity did not decrease in the $\mathrm{DH}$ of nonallodynic rats. $\boldsymbol{H}$, Fluorescent agrin particles in $\boldsymbol{G}$ measured by ImagePro Plus. There is a significant difference in the particles between allodynic (186 \pm 16$)$ and nonallodynic (706 \pm 55$)$ or sham $(625 \pm 57)$ rat $\mathrm{DH}(p<0.01$; one-way ANOVA, followed by the Mann-Whitney test. $n=6$ rats). $I$, Double staining for GAP43 (a neuronal marker) and agrin. When agrin (red) and GAP43 (green) were merged, the staining became yellow (arrow), suggesting that agrin is colocalized with GAP43. J, Double staining for agrin and GFAP. No yellow staining was observed on the merged images, suggesting that agrin is not colocalized with glial cells. $\boldsymbol{K}$, Agrin decreased at day 7 after PCI. Agrin immunoreactivity decreased in the $\mathrm{DH}$ only in the allodynic rats, showing a similar pattern to that in the CCI model. $\boldsymbol{L}$, Agrin fluorescent particles represented in $\boldsymbol{K}$. There are significant differences between sham (663 \pm 42$)$, nonallodynic (211 \pm 18$)$, and allodynic (741 \pm 35$)$ DH ( $p<0.01$; one-way ANOVA, followed by the Mann-Whitney test; $n=6$ rats; see supplemental Fig. S1, available at www.jneurosci.org as supplemental material, which shows that when neuropathic pain was resolved, agrin was restored to preinjury levels). $\boldsymbol{M}$, Agrin decreases in the dorsal root ganglia of neuropathic rats. The agrin immunoreactivity is decreased in the allodynic DRGs (Allo, arrows), compared to that in the sham (Sham) and nonallodynic (N-Allo) DRGs at day 7 after injury. The agrin decrease only occurs in the allodynic DRGs, consistent with the results from the DH. The bar graph shows that there is a significant difference for the agrin fluorescent particles between allodynic and sham or nonallodynic DRG (** $p<0.01$, one-way ANOVA, followed by the MannWhitney test; $n=4$ rats).

\section{NMDA induces agrin downregulation in culture}

Spinal hyperexcitability after peripheral nerve injury is involved in neuropathic pain development. Excitatory neurotransmitter glutamate and aspartate released from the DH increases 250$500 \%$ in allodynic rats under nonstimulated conditions; hyperexcitability is an underlying consequence of injury signals (J.-G. Cui et al., 1997). Thus, NMDA receptors on secondary neurons are excessively stimulated (McMahon et al., 1993). Substance P is released also, which further enhances overexcitability by removing the magnesium block (Mayer et al., 1984). To test whether NMDA receptor signaling participates in modulation of $\mathrm{DH}$ agrin, we used a thin-slice dorsal lumbar spinal cord culture. We found that NMDA $(100 \mu \mathrm{M})$, applied to the medium, resulted in downregulation of agrin (both mRNA and protein) after $24 \mathrm{~h}$ (Fig. $2 B, C$ ). Furthermore, NMDA plus Substance P further decreased agrin expression (Fig. $2 B, C$ ). When the NMDA antagonist MK801 was applied to the culture with NMDA, agrin decrease was blocked. Although NMDA stimulation in spinal tissue culture and intrathecal NMDA stimulation in living rats cannot fully mimic nerve injury-induced signal cascade changes, these results suggest that excessive NMDA receptor activation causes agrin downregulation in the spinal cord. NMDA also significantly reduced agrin in the DH when NMDA was infused into the rat spinal canal by an osmotic pump in a dose-dependent manner (Fig. 2D-F), concomitant with lower back and leg skin allodynia.

\section{Preemptive SCP1 prevents allodynia development}

SCP1, an APAP analog (Vaccarino et al., 2007), displays suppressive effects on neuropathic pain and voltage-gated calcium current in DRG neurons (Cui et al., 2006). Since enhanced excitability in spinal neurons before nerve injury accelerates neuropathic pain development (J.-C. Cui et al., 1997), we tested whether preemptive treatment with SCP1 would prevent neuropathic pain development. SCP1, injected intrathecally just before CCI, prevented allodynia development, as evidenced by unchanged paw-withdrawal thresholds (Fig. $3 A$ ). In rats with preemptive vehicle treatment, average thresholds decreased significantly at days 3 and 7 after injury. Agrin was downregulated at days 3 and 7 after CCI in vehicle-treated, allodynic rats, while preemptive treatment with SCP1 abolished agrin downregulation (Fig. 3B$E$ ). However, preemptive APAP treatment did not prevent threshold decrease at day 7 after injury, but it did delay allodynic development at day 3 after injury, when agrin protein decrease was small (Fig. $3 E$ ). In rats with preemptive SCP1 treatment, allodynia did not occur without a decrease in agrin in the $\mathrm{DH}$, as shown by behavioral, RT-PCR, and Western blot tests (Fig. 3A$E$ ). Supplemental Figure S2, $A$ and $B$ (available at www.jneurosci. org as supplemental material), shows changes in band intensity for $25 \mathrm{kDa}$ and $50 \mathrm{kDa}$ agrin in SCP1- and vehicle-pretreated rats. These results provide further support for the involvement of agrin in neuropathic pain development.

We further examined agrin immunostaining in L4-5 spinal cords with pretreatments at day 7 after injury. Pretreatment with vehicle or APAP did not increase $\mathrm{DH}$ agrin immunoreactivity (Fig. 3F, G; see supplemental Fig. S2C, available at www. jneurosci.org as supplemental material, for whole $\mathrm{DH}$ ). In contrast, pretreatment with SCP1 upregulated agrin sevenfold in the $\mathrm{DH}$ compared to the allodynic $\mathrm{DH}$, twofold compared to the nonallodynic $\mathrm{DH}$, and suppressed tactile allodynia development. As shown in Figure 1, agrin was colocalized with neuronal marker GAP43; thus, agrin increase in DH neurons is associated with suppression of neuropathic pain development. 
A
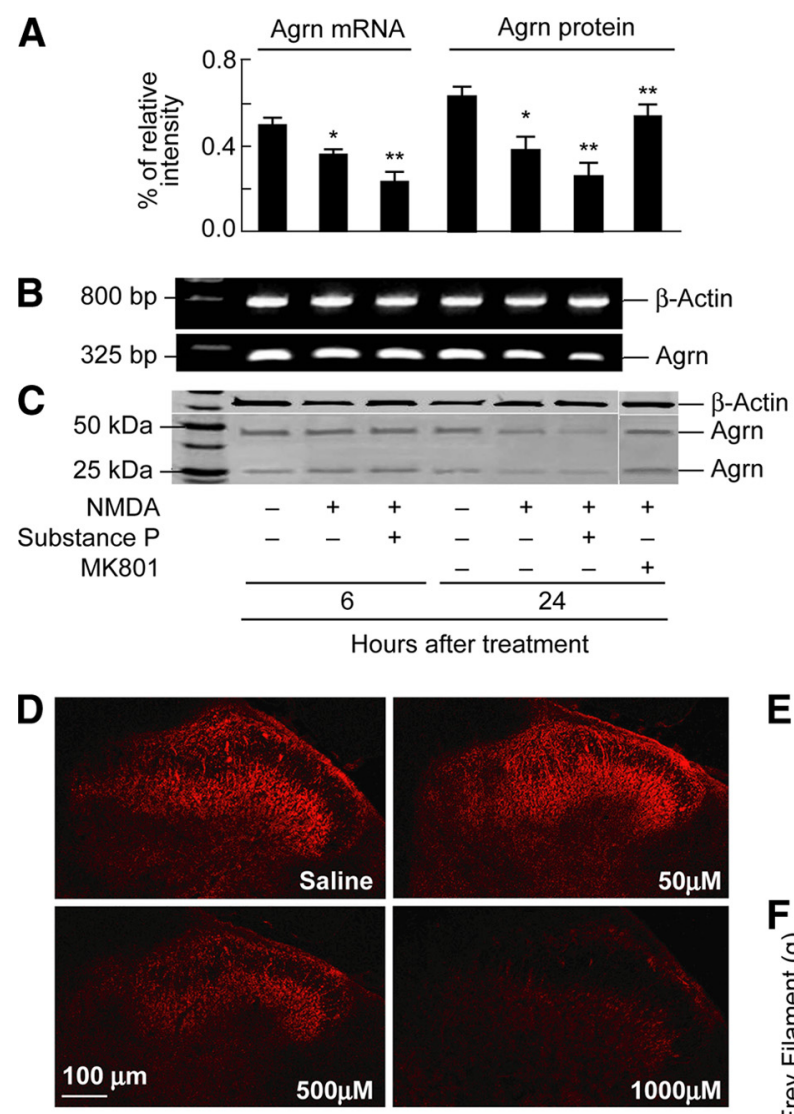

As shown in behavioral studies, intrathecal SCP1 and SCP-M1 suppressed tactile allodynia and thermal hyperalgesia in neuropathic rats, suggesting that the suppression is agrin related. At $1.5 \mathrm{~h}$ after SCP1 injection, we also observed agrin protein increase along with axons in the $\mathrm{DH}$, as revealed by immunostaining (Fig. $3 \mathrm{H}$, right panel).

\section{Intrathecal agrin siRNA blocks SCP1 effects}

To more directly evaluate agrin's role in SCP1-induced suppression of tactile allodynia, agrin siRNAs were used. An mRNA's siRNA can be assembled into endoribonuclease-containing complexes to cleave the mRNA (McManus and Sharp, 2002). If agrin siRNA prevents SCP1's effects on allodynic rats, as reported in other siRNA experiments (Fire et al., 1998; Kennedy et al., 2004), this will provide strong support for the concept that agrin is an inhibitory molecule in SCP1-induced suppression of allodynia.

Continual infusion of agrin siRNA (100 nM, which was effective in inhibiting agrin mRNA upregulation in our pilot studies) by an osmotic pump into the spinal cord immediately after intrathecal SCP1 injection blocked inhibition of tactile allodynia (Fig. 4A). We collected the L4-5 spinal cords for Western blot and immunostaining from allodynic rats with SCP1 or SCP1 plus agrin siRNA at $2 \mathrm{~h}$ after injection. Western blot analysis confirmed lack of agrin protein upregulation (Fig. $4 B$ ). In contrast, a nonfunctional siRNA (nFsiRNA, which lacks the ability to cleave agrin mRNA as a control) was administered together with SCP1 into allodynic rats; this did not halt the effects of SCP1 on tactile allodynia (Fig. $4 A$ ). At the same time, agrin upregulation was not affected by infusion of nFsiRNA (Fig. 4C).

Figure 2. NMDA decreases agrin in dorsal spinal cord culture. $\boldsymbol{A}$, Depicts relative intensity for agrin mRNA and protein be after $24 \mathrm{~h}$ of NMDA (100 $\mu \mathrm{m})$ exposure. The relative intensity, which was summarized from NMDA-induced agrin gene $(\boldsymbol{B})$ and protein ( $)$ decrease at $24 \mathrm{~h}$ after stimulation, was significantly decreased. MK801 (20 $\mu \mathrm{m})$ blocked NMDA-induced ag in decrease. The relative intensity for both mRNA and protein bands is significantly lower in NMDA-treated and NMDA plus SP-treated than in NMDA-treated cultures $\left({ }^{*} p<0.05 ;{ }^{* *} p<0.01\right.$; one-way ANOVA, followed by the Mann-Whitney test; $n=6$ wells for each group). At $6 \mathrm{~h}$ after stimulation, neither the agrin gene nor the protein changed. $\boldsymbol{D}$, NMDA infusion induces agrin decrease in the DH. NMDA of 1000,500 , and $50 \mu \mathrm{m}$ was infused via an osmotic pump, resulting in agrin decrease in the DH in a dose-dependent manner. Simultaneously, the NMDA induced tactile allodynia on the back and leg skin $(\boldsymbol{F})$, and NMDA $1000 \mu$ m produced allodynia (down to $0.2 \mathrm{~g}$ ). The results suggest that agrin decrease in the $\mathrm{DH}$ is a consequence of NMDA receptor overstimulation. $\boldsymbol{E}$, Bar graph summarizing measurement of agrin fluorescent particles. There is a significant difference between saline-infused or $50 \mu \mathrm{M}$ NMDA-treated and 500 or $1000 \mu \mathrm{M}$ NMDA-treated rats ( $n=6$ rats each group; ${ }^{* *} p<0.01$, one-way ANOVA, followed by the Mann-Whitney test). No agrin decrease was seen in the $\mathrm{DH}$ of the rats treated with $50 \mu \mathrm{m}$ NMDA.

\section{Intrathecal SCP1 upregulates agrin}

In preemptive studies, SCP1 prevented tactile allodynia development associated with $\mathrm{DH}$ agrin upregulation (Fig. $3 A-C, F$ ). We wanted to know whether SCP1 would also upregulate agrin in the $\mathrm{DH}$ of allodynic rats to suppress pain. First, we checked agrin gene expression after SCP1 administration. SCP1 increased agrin mRNA markedly at 1 and $2 \mathrm{~h}$ after injection, compared to that of vehicle-treated and allodynic rats (Fig. $3 H$ ).

Because SCP1 and SCP-M1 (the active metabolite of SCP1) reached the maximal suppressive effect on tactile allodynia within $1.5 \mathrm{~h}$, we chose the time point $2 \mathrm{~h}$ after injection to examine agrin protein levels in the DH. Agrin immunohistochemistry in L4 -5 spinal cords after intrathecal SCP1, SCP-M1, APAP, and vehicle injection showed that agrin was not increased in APAPand vehicle-treated allodynic rats, while agrin was increased eightfold in the DH of SCP1- and SCP-M1-treated allodynic rats (Fig. 3I,J). See supplemental Figure S2D (available at www. jneurosci.org as supplemental material) for the whole DH profile.
Moreover, when agrin siRNA was perfused into the spinal canal in normal rats, it produced allodynia $2 \mathrm{~d}$ after treatment (see supplemental Fig. $\$ 4 E$, available at www.jneurosci.org as supplemental material).

We explored mechanisms for agrin-induced pain suppression and found that SCP1- and SCP-M1-induced pain suppression was associated with an increase of phosphorylated NMDA receptor NR1 subunits ( $\mathrm{p}-\mathrm{NR} 1$ ) in the DH. We also observed that agrin siRNA blocked p-NR1 increase (Fig. $4 D, E$ ). We will discuss these observations in greater detail below.

Agrin delivered by AAV-Ag vectors inhibits neuropathic pain To provide direct evidence for agrin's participation in pain modulation and to ascertain the agrin isoform involved, recombinant adeno-associated virus serum type 2 (AAV) vector was inserted with agrin sequence Ag50 or Ag25 (supplemental Fig. S3B, available at www.jneurosci.org as supplemental material). After sequencing, the AAV-Ag viruses were used for infecting HEK293 

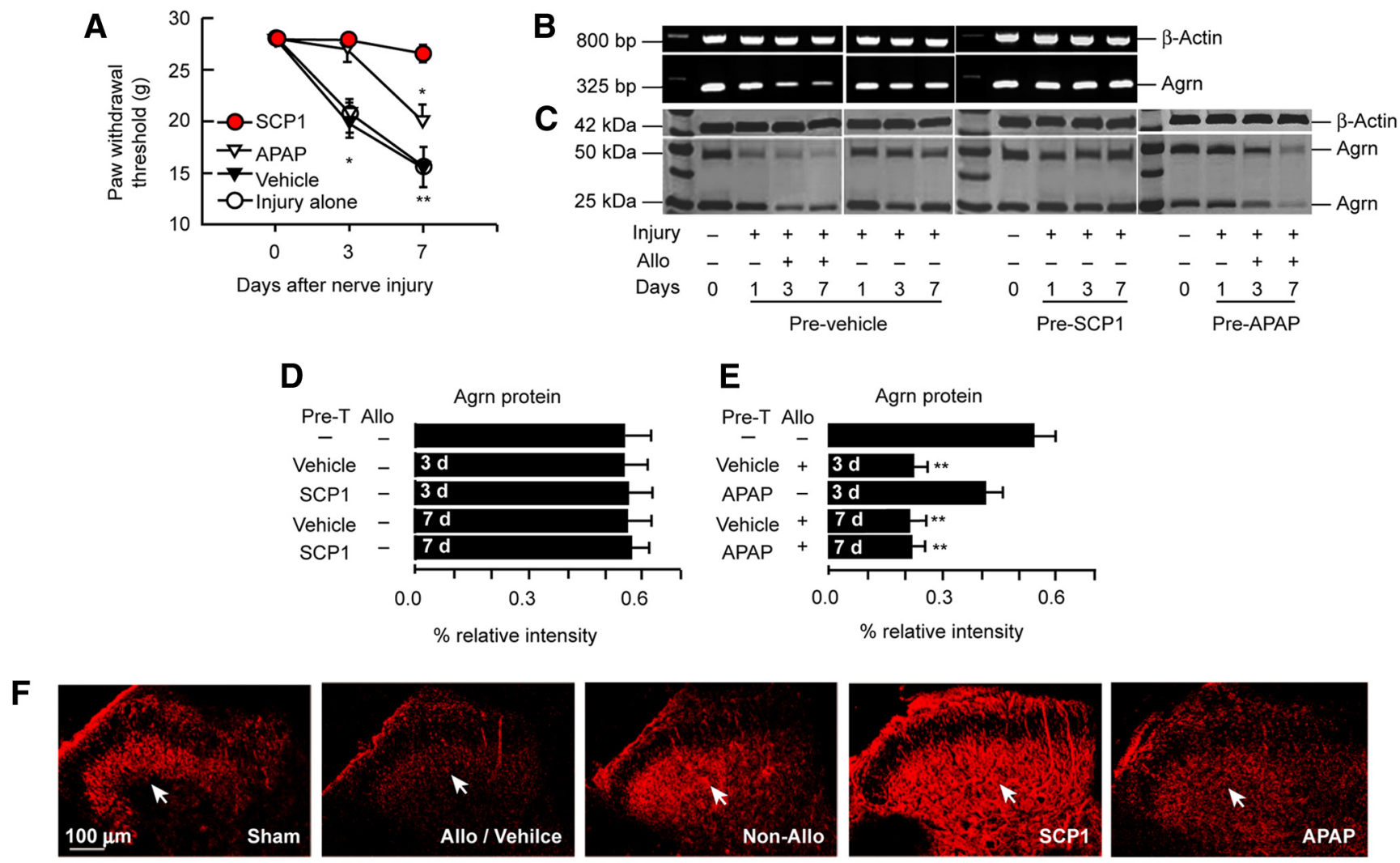

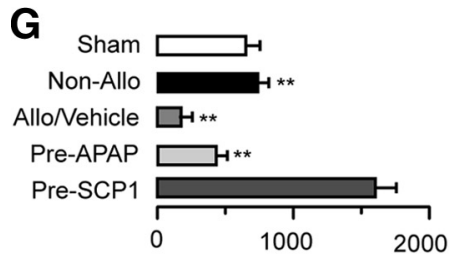

Agrn Fluor Particles
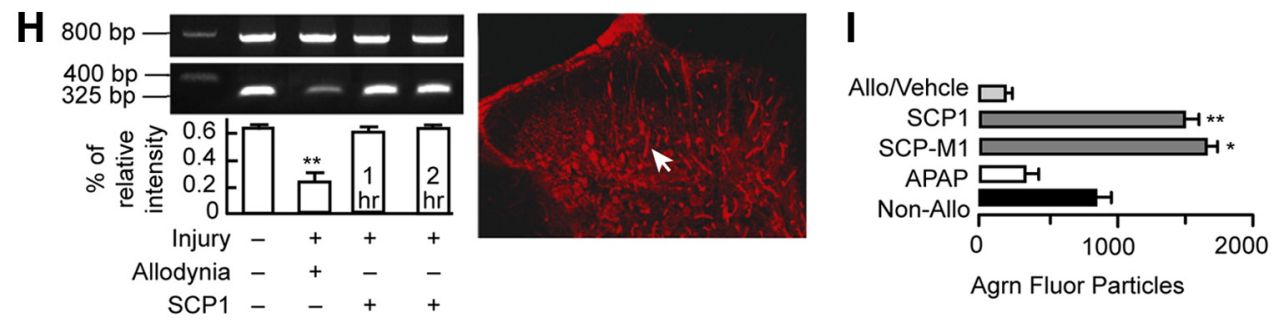

J
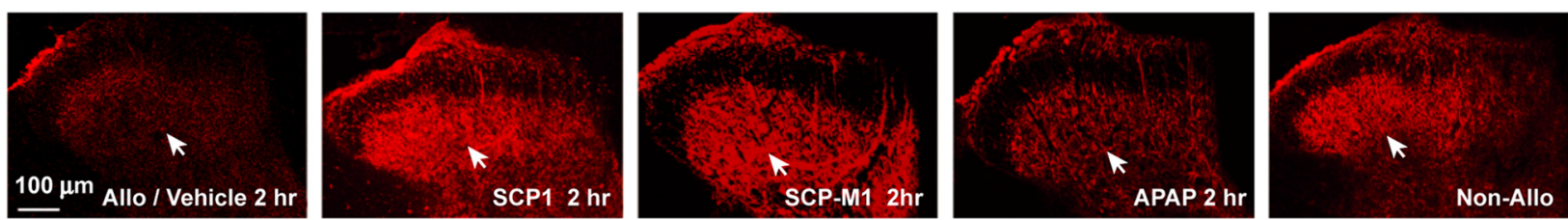

Figure 3. Agrin decrease is prevented by SCP1. $A$, Changes in paw withdrawal threshold induced by intrathecal preemptive drug treatments following nerve injury. SCP1 ( $n=12$ rats) prevented the threshold decrease at days 3 and 7 after nerve injury, while APAP $(n=10$ rats) delayed, but did not prevent, the threshold decrease. The fact that the withdrawal threshold with APAP-treated rats did not decrease significantly at day 3 after treatment may correspond to high levels of agrin in the $D H$, as shown in $C$ and $\boldsymbol{E}$. Also, vehicle pretreatment did not prevent the threshold decrease ( $n=12$ rats). Threshold decrease in APAP-treated, vehicle-treated, or injury-alone rats ( $n=9$ rats) was significant, compared to that of preinjury rats ( ${ }^{*} p<0.05$; ${ }^{* *} p<0.01$; one-way ANOVA, followed by Wilcoxon signed-rank test). There was a difference between SCP1-pretreated and APAP-pretreated, vehicle-pretreated, or injury-alone rats $\left({ }^{*} p<0.05\right.$; ${ }^{* *} p<0.01$; one-way ANOVA, followed by the Mann-Whitney test). $\boldsymbol{B}, \boldsymbol{C}$, SCP1, given intrathecally before nerve injury, prevented agrin gene $(\boldsymbol{B})$ and protein $(\boldsymbol{C})$ decrease at days 3 and 7 after treatment $(n=12$ rats), while prior injection of either vehicle $(n=36$ rats) or APAP ( $n=20$ rats) did not. APAP-pretreated rats had an allodynic incidence similar to that of vehicle-pretreated rats ( $34-40 \%)$. $\boldsymbol{D}, \boldsymbol{E}$, Summary of the relative intensity for agrin proteins ( $\boldsymbol{D}$, nonallodynic; $\boldsymbol{E}$, allodynic). The relative intensity is significantly higher in SCP1-pretreated than in vehicle-and APAP-pretreated groups. Also, there was a difference in relative intensity of proteins between APAP-pretreated and vehicle-pretreated rats at day 3 after treatment $\left({ }^{*} p<0.05 ;{ }^{* *} p<0.01\right.$; one-way ANOVA, followed by the Mann-Whitney test). The relative intensity for agrin mRNA is in supplemental Figure $\$ 2$ (available at www.jneurosci.org as supplemental material). $F$, Rats pretreated with SCP1, APAP, or vehicle, including sham and nonallodynic rats, had the $L 4-5$ spinal cord removed at day 7 after injury ( $n=5$ rats) for agrin immunostaining. Agrin immunoreactivity was markedly reduced in laminae I-III in allodynic/vehicle-and APAP-pretreated rats, while SCP-pretreated rats had greater increases in immunoreactivity in the DH. The increase in DH agrin immunoreactivity correlates with the prevention of tactile allodynia development as shown in $\boldsymbol{A}$ (see supplemental Fig. S2C, available at www.jneurosci.org as supplemental material, for whole DH profiles). $\boldsymbol{G}$, DH agrin fluorescent particles measured by ImagePro Plus. Comparisons for the particles between SCP1-pretreated and APAP-pretreated or vehicle-pretreated allodynic rats are significant $\left({ }^{* *} p<0.01\right.$; one-way ANOVA, followed by the Mann-Whitney test; $n=4$ rats for each group). $\boldsymbol{H}$, Intrathecal SCP1 increases agrin mRNA in neuropathic rats. A bolus injection of SCP1 (100 nmol) given intrathecally to allodynic rats led to agrin upregulation at 1 and $2 \mathrm{~h}$ after injection, while agrin mRNA did not increase after vehicle injection. The relative intensity of agrin gene bands is illustrated on the lower panel. The relative intensity increase in SCP1 injection was significant, compared to that in vehicle injection ( $n=5$ rats; ${ }^{* *} p<0.01$; one-way ANOVA, followed by the Mann-Whitney test). Increased agrin expression along with axons was observed in the DH (arrow) at $1.5 \mathrm{~h}$ after SCP1 injection. $I, J$, Intrathecal SCP1 promotes agrin expression in the neuropathic DH. When SCP1 or SCP-M1 was intrathecally administered into neuropathic rats, agrin immunoreactivity was increased in the laminae I-IV of the DH at $2 \mathrm{~h}$ after treatment (arrow), while no agrin increase was observed in APAP-orvehicle-treated neuropathic rats (arrow). Compared to nonallodynic rats, agrin immunoreactivity was downregulated in the $\mathrm{DH}$ of allodynic ones ( $n=8$, each treatment). The agrin protein increases in the DH were parallel to the suppression of tactile allodynia induced by intrathecal SCP1 (Fig. 4A), suggesting that agrin is engaged in the suppression. $I$, Agrin fluorescent particles in the DH measured by ImagePro Plus. There are significant differences between SCP1- or SCP-M1-treated and vehicle- or APAP-treated rats ( ${ }^{*} p<0.05 ;{ }^{* *} p<0.01$; one-way ANOVA, followed by the Mann-Whitney test). 


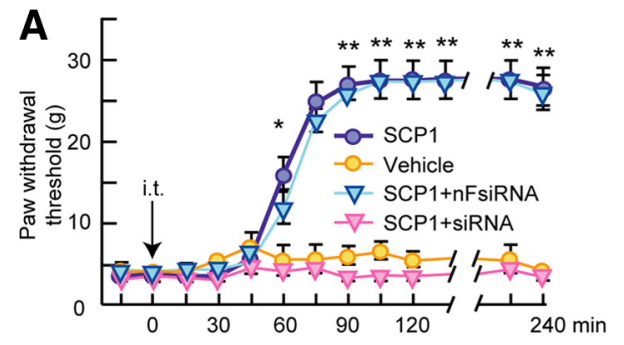

B
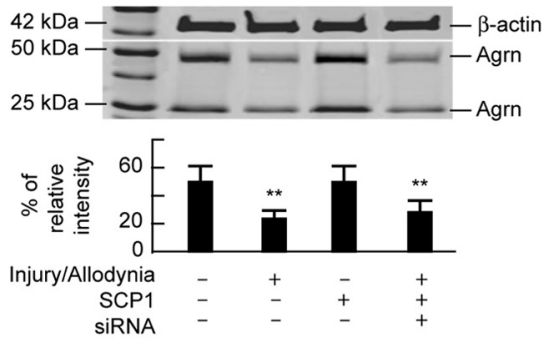

C
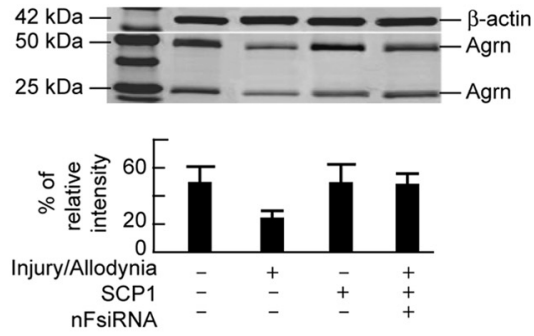
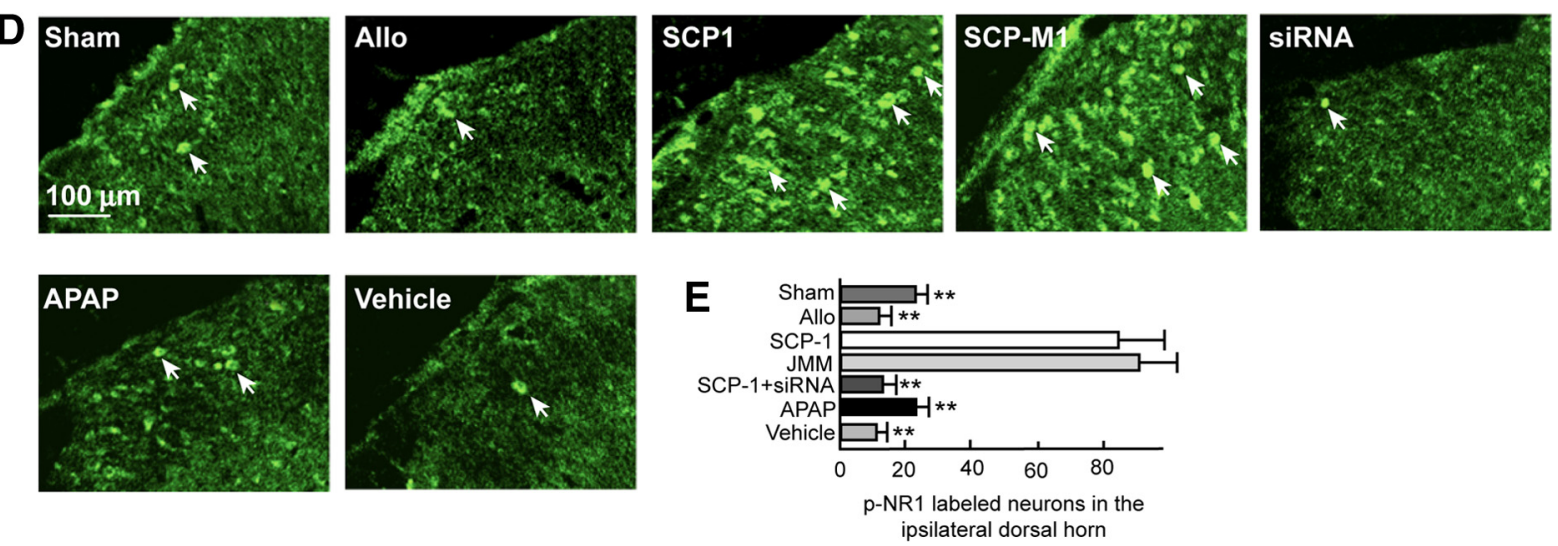

Figure 4. Agrin induces phosphorylation of NMDA receptor NR1 subunits. $\boldsymbol{A}$, Intrathecal SCP1 normalized the paw withdrawal threshold in the allodynic rats. When agrin siRNA (100 nm) was continuously infused into the spinal canal at $5 \mu \mathrm{l} / \mathrm{h}$ immediately after an intrathecal bolus injection of SCP1 ( $100 \mathrm{nmol}$; the pump was linked to the catheter and immersed in $37^{\circ} \mathrm{C}$ water), the siRNA inhibited SCP1-induced withdrawal threshold elevation in 14 out of 17 rats, assessed by von Frey filaments. However, no inhibition occurred when $\mathrm{nFsiRNA}$ was administered. $\boldsymbol{B}, \boldsymbol{C}$, At $2 \mathrm{~h}$ after treatment, Western blot analysis revealed that neither $25 \mathrm{kDa}$ nor $50 \mathrm{kDa}$ agrin proteins in siRNA plus SCP1-treated rats were increased (B), compared to that of SCP1-treated or SCP1-nFsiRNAtreated rats (C).D,E, Phosphorylation of NR1 subunits after intrathecal SCP1 or SCP-M1. An antibody targeting p-NR1 subunits at serine residue $896 / 897$ was used for labeling the DH cells at $2 \mathrm{~h}$ after drug administration. In the sham DH, a few p-NR1-positive neurons (green fluorescence, arrows) were observed, while even fewer p-NR1-positive neurons were seen in the allodynic DH. Vehicle injection did not change the number of p-NR1-positive neurons. In contrast, SCP1 or SCP-M1 remarkably upregulated p-NR1-positive neurons in the DH. When agrin siRNA was given together with SCP1, the upregulation of p-NR1-positive neurons was abolished. Average p-NR1-positive neurons counted from 6 rats are summarized in $\boldsymbol{E}$. In SCP1- and SCP-M1-treated rats, the p-NR1-positive neurons were upregulated to 82 and 89 , respectively, while the number was 10 in vehicle-treated rats, 11 in allodynic rats, and 24 in sham rats. When siRNA was applied together with SCP1, the neurons were 12, suggesting that agrin siRNA inhibited the phosphorylation at the NR1 serine residue site. APAP did not induce changes in the p-NR1 neurons observed. Comparison of $p$-NR1positive cells between SCP1-treated and vehicle-treated or allodynic rats was significant ${ }^{* *} p<0.01 ; n=4$ rats for staining). There was a significant difference for $p$-NR1-positive neurons between sham and allodynic rats ( ${ }^{*} p<0.05$; one-way ANOVA, followed by the Mann-Whitney test).

cells for harvesting viral particles (the virus vectors were made by Vector Biolabs). First, we injected AAV-GFP into the superficial $\mathrm{DH}$ to determine transfection efficiency. The results showed that GFP was present in many cells $48 \mathrm{~h}$ after injection (supplemental Fig. S3A, available at www.jneurosci.org as supplemental material). When stained with $\beta$-tubulin III antibody (a neuronal marker), GFP was colocalized with $\beta$-tubulin, suggesting that the $A A V$ vector preferably infected neurons in the DH (supplemental Fig. S3C, available at www.jneurosci.org as supplemental material). We also examined the damage to the spinal cord made by the needle insertion. The damage was very small (supplemental Fig. S3A, available at www.jneurosci.org as supplemental material), and no adverse signs were observed in the injected animals.

When $5 \times 10^{10} \mathrm{GC}$ of AAV-Ag50 were injected into the superficial DH of neuropathic rats, the paw withdrawal threshold started increasing at $24 \mathrm{~h}$. The threshold was normalized at $48 \mathrm{~h}$ after injection (Fig. 5D). The effect lasted for the entire $7 \mathrm{~d}$. AAVAg50 injection also normalized thermal hyperalgesia (Fig. 5E). Neither AAV-Ag2 5 nor AAV-null of $5 \times 10^{10} \mathrm{GC}$, injected into the $\mathrm{DH}$, affected the threshold. Using Western blot analysis, we examined agrin protein expression in the spinal cord at $48 \mathrm{~h}$ after injection. We found that both Ag50 and Ag25 were expressed. The amounts of $50 \mathrm{kDa}$ and $25 \mathrm{kDa}$ agrin were highly increased when compared to that in the neuropathic DH or AAV-nullinjected DH. Fifty- and twenty-five-kilodalton agrin were also $m y c$ expressed (Fig. $5 F$ ), suggesting that the 50 and $25 \mathrm{kDa}$ proteins came from AAV-Ag vectors. These results indicate that 50 $\mathrm{kDa}$ agrin is an active protein, because only the $50 \mathrm{kDa}$-agrin increase suppressed neuropathic pain in behavioral tests.

\section{Agrin induces NMDA receptor NR1 subunit phosphorylation in GABA neurons}

NMDA receptor activation via phosphorylation participates in modulation of neuronal excitability and excitotoxicity. Here, NMDA receptor activation resulted in agrin downregulation, whereas agrin upregulation by AAV-Ag50 or SCP1 suppressed tactile allodynia. Therefore, we tested the hypothesis that NMDA receptor phosphorylation may be involved in agrin-induced allodynia suppression. We found that in allodynic rats, AAV-Ag50 or SCP1 induced upregulation of p-NR1 in the DH (Figs. $4 D, E$, $5 A)$. SCP-M1 also increased p-NR1 when injected intrathecally. However, no increase in p-NR1-positive cells was observed in the $\mathrm{DH}$ of vehicle-, AAV-null-, or AAV-Ag25-treated rats (Fig. $5 A, B)$. The p-NR1 antibody indicates that the phosphorylated sites are located on serine residue $896 / 897$ of the NR1 subunits. In the behavioral study, upregulation of $\mathrm{p}-\mathrm{NR} 1$ and $50 \mathrm{kDa}$ agrin was associated with suppression of tactile allodynia and thermal hyperalgesia. When agrin siRNA was applied together with AAVAg50 or SCP1 using the same method as above, siRNA blocked phosphorylation, agrin upregulation, and tactile allodynia sup- 
A
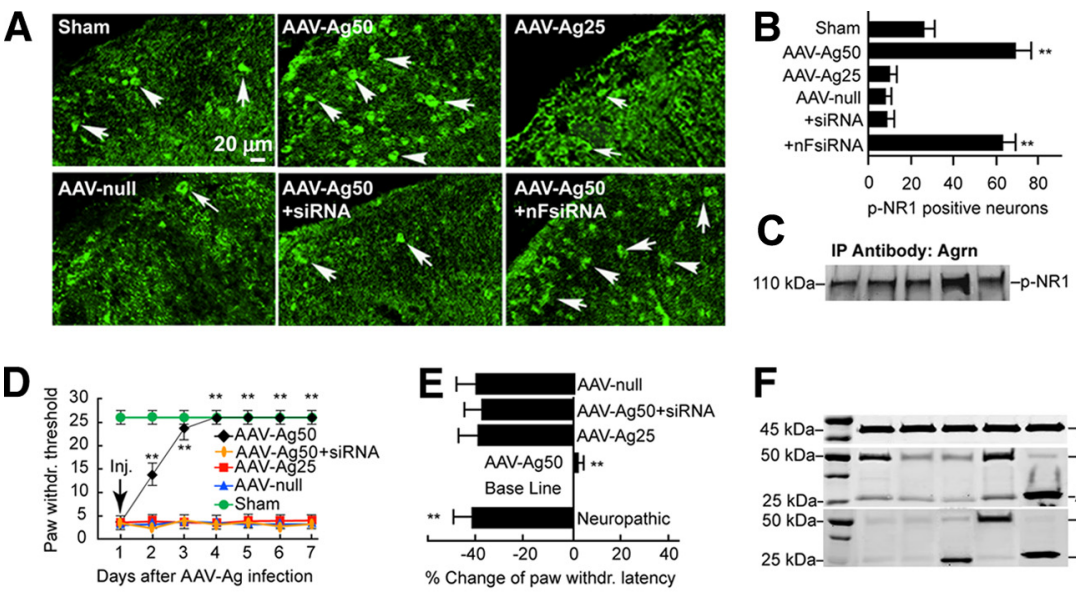

G
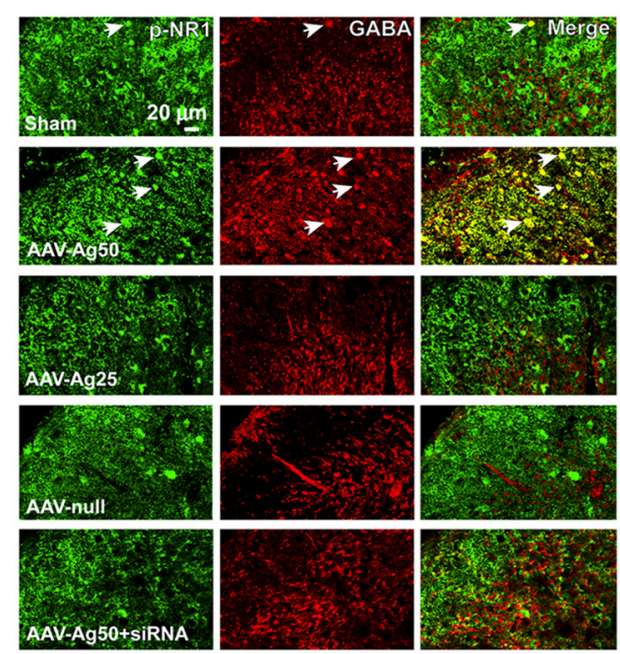

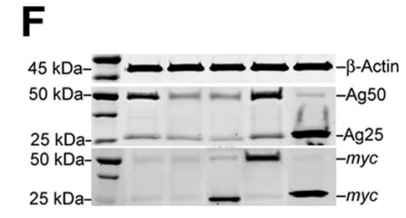

H

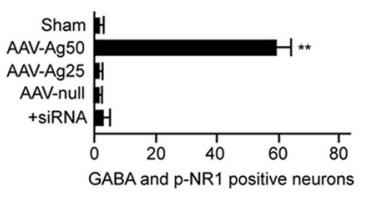

I
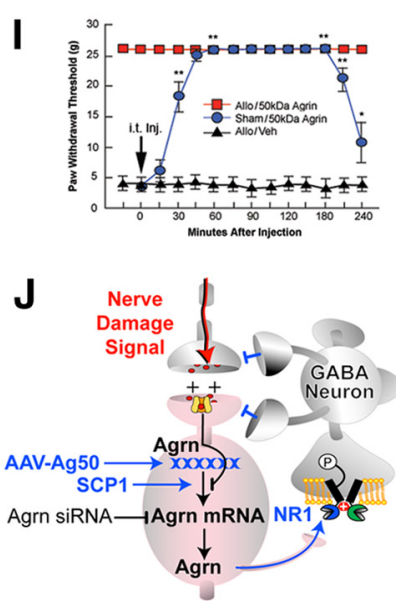

Figure 5. AAV-Ag50 upregulates p-NR1 in inhibitory GABA interneurons. $A$, AAV-Ag50 vector injection into the DH induced phosphorylation of NR1 subunits in the DH of neuropathic rats, while AAV-Ag25 and AAV-null vectors did not. Agrin siRNA, administered continually via osmotic pump immediately after VVA2-Ag50 vector injection, blocked the effect of the $50 \mathrm{kDa}$ agrin on phosphorylation. $B, A A V-A g 50$ induced the number of p-NR1-positive neurons twofold more than sham, and sevenfold more than AAV-Ag25 and AAV-null ( $n=6$ rats). $C$, The samples loaded for agrin immunoprecipitation are, from left to right: sham, neuropathic, AAV-null-treated, AAV2-Ag50-treated, and AAV-Ag25-treated samples. The bands labeled by p-NR1 antibody are clearly displayed on the membrane, indicating that agrin interacts with p-NR1. D, The average paw withdrawal threshold was increased and normalized by AAV-Ag50 injection into the DH of neuropathic rats at $48 \mathrm{~h}$ after injection ( $n=12$ rats). AAV-Ag25 and AAV-null injections did not change the threshold. $\boldsymbol{E}$, The paw withdrawal latency dropped $40 \%$ compared to preinjury baseline on the hot plate. AAV-Ag50 normalized the latency, while AAV-Ag25 and AAV-null did not. $\boldsymbol{F}$, Western blot for agrin and myc antibody from the treated spinal cord samples at $48 \mathrm{~h}$ after injection. Samples were loaded to the lanes from left to right the same as in $\mathbf{C}$. Fifty- and twenty-five-kilodalton agrins were markedly increased, compared to those of neuropathic and AAV-null-treated animals. The samples of AAV-vector-treated animals were also myc positive, suggesting that $50 \mathrm{kDa}$ and $25 \mathrm{kDa}$ proteins came from the vectors' expression (see supplemental Fig. S4D, available at www.jneurosci.org as supplemental material, for band intensity summary). G, GABA (red) and p-NR1 (green) double staining shows that a few cells are both GABA and p-NR1 positive in the sham DH. In the AAV-Ag25- and AAV-null-treated DH, even fewer GABA and p-NR1-positive cells were observed. In contrast, many GABA and p-NR1-positive cells are displayed in the AAV-Ag50-treated DH (arrows). $\boldsymbol{H}$, The cell count from laminae I-IV in 6 rats indicates that the number for AAV-Ag50 treatment is up to 10-fold greater than those for AAV-Ag25 and AAV-null treatments and for sham rats. ( ${ }^{* *} p<0.01$, one-way ANOVA, followed by the Mann-Whitney test). I, Purified $50 \mathrm{kDa}$ agrin of $2 \mathrm{ng}$ (in $10 \mu$ l of artificial (SF) was intrathecally injected into allodynic rats $(n=6)$ and sham-operated rats $(n=5)$. At $30 \mathrm{~min}$ after injection, the average paw withdrawal threshold was significantly elevated in allodynic rats. At 45 min after injection, the threshold was normalized. The agrin inhibitory effect lasted for almost $4 \mathrm{~h}$. However, the agrin intrathecal injection did not change the withdrawal threshold in sham-operated rats. The vehicle (10 $\mu$ l of artificial CSF) intrathecal injection did not affect the paw withdrawal threshold in allodynic rats $(n=4)$. There is a significant difference for the withdrawal threshold between $50 \mathrm{kDa}$ agrin-treated and vehicletreated neuropathic rats $\left({ }^{*} p<0.05 ;{ }^{* *} p<0.01\right.$; one-way ANOVA, followed by the Mann-Whitney test).J, Illustration depicting the agrin modulatory mechanism. Following peripheral nerve injury, damage signals produce agrin decrease in sensory neurons, resulting in neuropathic pain. When AAV-Ag50 vectors enter the sensory neurons and are integrated into chromosome $19,50 \mathrm{kDa}$

pression, indicating that these effects stemmed from agrin (Figs. $4 A, B, D, E$, $5 A, B, D, E)$. To verify whether agrin interacts with p-NR1, we used a monoclonal agrin antibody to bind to IgG-coated beads to test whether agrin pulls down p-NR1. We observed the p-NR1 band on the Western membrane (Fig. 5C) and noted that agrin did interact with p-NR1. We considered that $\mathrm{p}-\mathrm{NR} 1$ increase correlated with neuropathic pain suppression, suggesting that p-NR1 leads to an inhibitory effect on sensory neurons. However, several articles reported that p-NR1 results in neuropathic pain in the rat CCI and Chung models (Ultenius et al., 2006; Gao et al., 2007; Roh et al., 2008). We then considered that if $\mathrm{p}-\mathrm{NR} 1$ occurs in sensory or excitatory interneurons, its activation would facilitate pain. However, if p-NR1 occurs in inhibitory interneurons, its excitation would inhibit activation of sensory or postsynaptic neurons, and thus suppress pain. Therefore, we further examined whether or not p-NR1 induced by $50 \mathrm{kDa}$ agrin occurs in inhibitory interneurons containing GABA, an inhibitory neurotransmitter (Hildebrand et al., 1992; McBain and Fisahn, 2001). The double staining of p-NR1 plus GABA antibodies revealed that $\mathrm{p}-\mathrm{NR} 1-$ positive neurons were colocalized with GABA-positive neurons in the DH (Fig. 5G; see supplemental Fig. S3D, available at www. jneurosci.org as supplemental material, for a three-dimensional reconstruction). Intrathecal SCP1 also induced phosphorylation in GABA-positive neurons (supplemental Fig. S3E, F, available at www.jneurosci.org as supplemental material). We observed that agrin did not colocalize with GAD65/67 (supplemental Fig. S4A, $B$, available at www.jneurosci.org as supplemental material). Altogether, these results indicate that phosphorylation of NR1 subunits occurs in GABA inhibitory interneurons and that activation of these interneurons suppresses neuropathic pain. To further evaluate $50 \mathrm{kDa}$ agrin effects in vivo, we injected purified $50 \mathrm{kDa}$ agrin into neuro-

$\leftarrow$

agrin is upregulated and released presynaptically to bridge serine/threonine kinase to phosphorylate NR1 subunits [the NR1 structure is described by Furukawa et al. (2005)] in the GABA interneurons (agrin is not in the GABA neurons, as shown in supplemental Fig. S4, available at www.jneurosci. org as supplemental material). Therefore, excitation of the GABA neurons inhibits presynaptic and postsynaptic sensory neurons. SCP1 also upregulates agrin, probably via enhancing gene transcription, and induces $p$-NR1 in the GABA neurons. When agrin siRNA was applied together with AAV-Ag50 or SCP1, the siRNA inhibited agrin mRNA upregulation, resulting in no agrin increase, no p-NR1, and no pain suppression. 

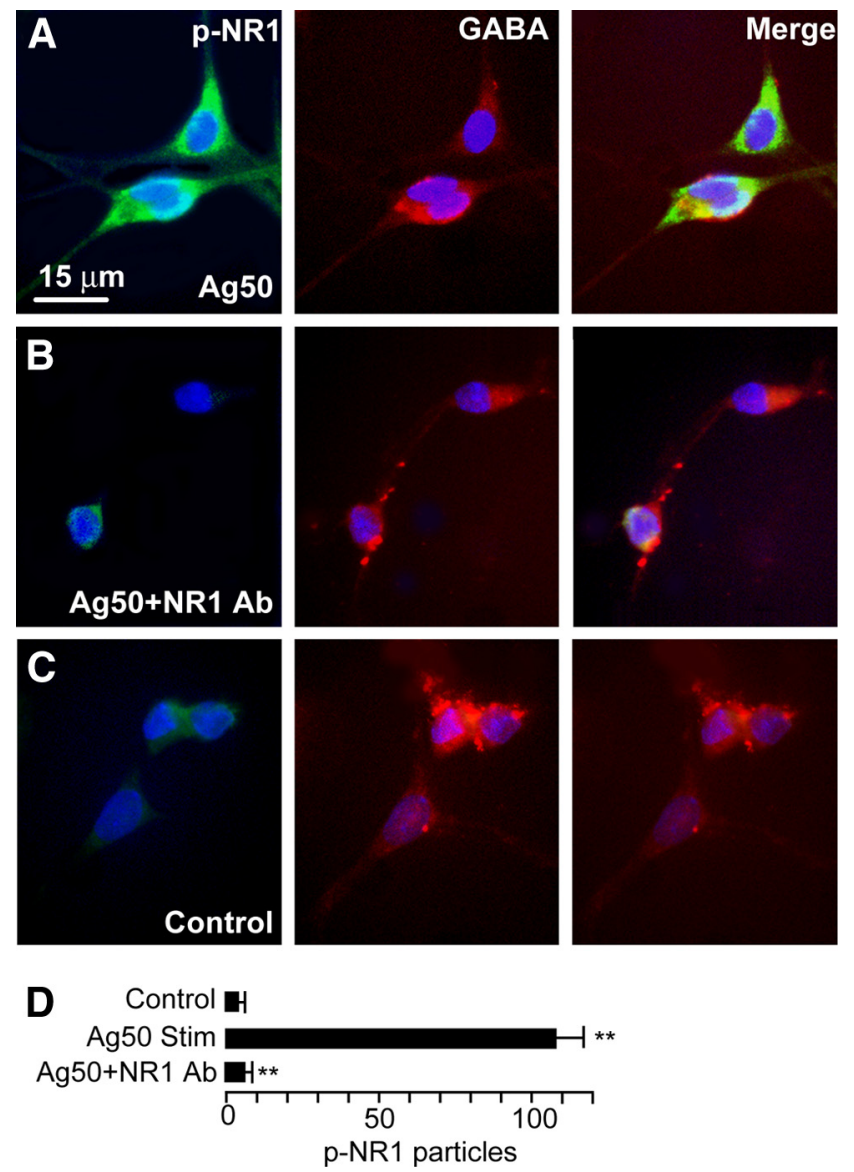

Figure 6. Purified $50 \mathrm{kDa}$ agrin induces $\mathrm{p}-\mathrm{NR} 1$ in sorted GABA cell culture. $\boldsymbol{A}$, Purified $50 \mathrm{kDa}$ agrin protein was added to culture medium of dorsal spinal GAD65-positive cells, sorted by FACS from 7-10 d postnatal rats. p-NR1 fluorescence particles (green) increased within 15 min. GABA antibody staining confirmed that these cells were GABA-positive neurons. $\boldsymbol{B}$, When an NR1 antibody, which targets the NR1 810-910 aa domain, was incubated for 30 min before addition of $50 \mathrm{kDa}$ agrin, the antibody blocked agrin-induced phosphorylation. $C$, In contrast, the GAD65positive cells did not show p-NR1 increase without addition of $50 \mathrm{kDa}$ agrin (for GAD65-positive cell sorting and $50 \mathrm{kDa}$ agrin purification, see supplemental Fig. S5, available at www.jneurosci. org as supplemental material). These observations further support the notion that agrin induces p-NR1. D, The comparisons for p-NR1 particles between the agrin-treated cells and those treated with NR1 antibody plus agrin or controls yield significant differences ( $n=6$ wells; ${ }^{*} p<$ 0.001; one-way ANOVA, followed by the Mann-Whitney test).

pathic rats. We found that $2 \mathrm{ng}$ of agrin (in $10 \mu \mathrm{l}$ of artificial CSF), given intrathecally into neuropathic rats, normalized the abnormally low paw withdrawal threshold (Fig. 5I), and the effect lasted for up to $4 \mathrm{~h}$. However, the $50 \mathrm{kDa}$ agrin did not affect the paw withdrawal threshold in sham-operated rats, suggesting that the agrin produces an inhibitory effect in the $\mathrm{DH}$.

\section{$50 \mathrm{kDa}$ agrin activates NR1 subunits phosphorylation in the} sorted GABA cell culture

Using GAD65-sorted dorsal spinal GABA cells in culture, we then explored direct evidence as to whether addition of purified 50 $\mathrm{kDa}$ agrin induces phosphorylation of NR1 subunits. Within 15 min of agrin addition, p-NR1-positive particles emerged on the membrane and inside the sorted cells (Fig. 6A). Cells without added agrin, however, did not display any $\mathrm{p}$-NR1-positive particles (Fig. 6C). Since NR1 phosphorylation occurs at serine residue $896 / 897$, we incubated the cells with an NR1 antibody, which targets the NR1 domain of 810-910 aa before the addition of agrin, to test whether or not the antibody prevents agrin from binding and inducing phosphorylation. No p-NR1 particles emerged as a result of these treatments (Fig. $6 \mathrm{~B}$ ). These observations suggest that $50 \mathrm{kDa}$ agrin indeed induces phosphorylation of NR1 subunits in the GABA neurons.

\section{Discussion}

Together, our results show that agrin plays a central role in mediating neuropathic pain development and suppressing neuropathic pain. Although both 25 and $50 \mathrm{kDa}$ agrin were found in the rat spinal cord, $50 \mathrm{kDa}$ agrin turned out to be the functional molecule for suppressing neuropathic pain through phosphorylating NMDA receptor NR1 subunits in GABA interneurons of the CCI and PCI rat models.

\section{$50 \mathrm{kDa}$ agrin suppresses neuropathic pain}

Following peripheral nerve injury in the CCI or PCI rat models, agrin decrease only occurred in the $\mathrm{DH}$ of rats that developed neuropathic pain. Agrin increase in the DH played a role in intrathecal SCP1-induced suppression of allodynia and preemptive SCP1-induced prevention of neuropathic pain development. Agrin's role was further strengthened by the observation that agrin levels were restored to preinjury levels when neuropathic pain was resolved. Although SCP1 upregulated both 50 and 25 $\mathrm{kDa}$ agrin, $\mathrm{AAV}-\mathrm{Ag} 50$ and $\mathrm{AAV}-\mathrm{Ag} 25$ vector injections in the $\mathrm{DH}$ confirmed that only $50 \mathrm{kDa}$ agrin, expressed by the vector, suppressed neuropathic pain. The effects of SCP1 and the AAV-Ag50 vector on pain suppression were blocked by intrathecal administration of agrin siRNA. These results suggest that $50 \mathrm{kDa}$ agrin is the functional molecule in the modulation of pain in the rat $\mathrm{DH}$.

\section{$50 \mathrm{kDa}$ agrin activates NMDA receptor NR1 subunits in GABA neurons}

So far, no report has described agrin interactions with NMDA receptors or the possible role of this interaction. NMDA receptors are a hub for sensory signal regulation. In rat spinal cords, $\sim 30 \%$ of NR1-labeled terminals are presynaptic (Liu et al., 1994), and the NMDA receptor complexes are mainly composed of NR1/NR2B/NR2D and NR1/NR2A/NR2D. Only NR1 has serine sites for phosphorylated action (Salter and Kalia, 2004), while NR2 has both serine and tyrosine sites (Dunah et al., 1999; Schrattenholz and Soskic, 2006). Phosphorylation of NR1 and NR2 subunits may occur in different neurons to modulate excitability of NMDA receptors (Rostas et al., 1996; Guo et al., 2002). Tyrosine kinase activates phosphorylation of NR2A and NR2B on tyrosine residues. As a result of tyrosine phosphorylation, NMDA receptor excitability is increased via calcium influx through the opening of ion channels. NR1 subunit phosphorylation is also associated with an increased EPSC in the striatal neurons (Chergui et al., 2005). Mechanistically, excitation or inhibition could result from agrin-induced phosphorylation of NR1 subunits. Our results demonstrate that the AAV-Ag50 vector and SCP1 treatment increase phosphorylated NR1-positive neurons in the $\mathrm{DH}$ and suppress neuropathic pain. However, other articles reported that increased NR1 phosphorylation enhances neuropathic pain (Gao et al., 2007; Roh et al., 2008). We demonstrated that $50 \mathrm{kDa}$ agrin expressed by AAV-Ag50 vector or SCP1 in HD sensory neurons induces NR1 phosphorylation in the inhibitory GABA interneurons, and such activation of the GABA neurons by phosphorylation inhibits excitation of sensory or postsynaptic neurons, thus suppressing pain. Double staining of agrin plus GFAP or agrin plus GAD65/67 (GABA neuronal marker) supports the notion that agrin is neither colocalized with glial cells nor GABA neurons. This concept is also supported by 
labeling of the neuronal marker, $\beta$-tubulin III, which shows that AAV-GFP preferably infects $\beta$-tubulin III-positive neurons in the DH (most DH neurons are, in fact, sensory neurons). Moreover, the agrin antibody pulled down $\mathrm{p}-\mathrm{NR} 1$ in the protein precipitation experiment, confirming that agrin binds to p-NR1. These results reveal that agrin is synthesized in the sensory neurons after the AAV-Ag50 vector is delivered into the $\mathrm{DH}$ and then is released presynaptically to phosphorylate NMDA receptor NR1 subunits in GABA interneurons. When GABA neurons are activated via this phosphorylation, pain is suppressed. Moreover, purified $50 \mathrm{kDa}$ agrin also suppressed neuropathic pain when given intrathecally into allodynic rats. These data corroborate the concept that $50 \mathrm{kDa}$ agrin-induced NR1 phosphorylation in the GABA interneurons is the key to neuropathic pain suppression.

\section{NR1 subunit contains a receptor for $50 \mathrm{kDa}$ agrin}

How does agrin induce NR1 phosphorylation? There is still little knowledge regarding this since the agrin receptor is so elusive. The molecules $\alpha$-dystroglycan (Bowe et al., 1994; Campanelli et al., 1994), integrins (Bowe and Fallon, 1995), rapsyn (Gautam et al., 1995), tyrosine kinase (Hilgenberg and Smith, 2004), MuSK (Glass et al., 1996; Kim and Burden, 2008), Lrp4 (Kim et al., 2008), and $\alpha \mathrm{Na} / \mathrm{K}$ ATPase (Hilgenberg et al., 2006) have been considered as agrin receptors or related to an agrin receptor. However, evidence indicates that some of these molecules are instead part of the agrin receptor construction, since none of them can fully explain the experimental results according to the criteria of a receptor. However, our results demonstrate that NR1 subunit phosphorylation at serine residue $896 / 897$ was activated by $50 \mathrm{kDa}$ agrin in the sorted DH GABA cell culture. The fact that agrin induces phosphorylation of NR1 subunits is also supported by studies showing that agrin induces cAMP response element binding protein phosphorylation in rat cell cultures (Ji et al., 1998). Moreover, when we used an NR1 antibody to seal the domain from 810 to 910 aa before adding purified $50 \mathrm{kDa}$ agrin, agrin no longer activated NR1 phosphorylation. These results indicate that agrin interacts with the NMDA receptor NR1 subunit of GABA neurons on the serine residue 896/897 segment domain. When $50 \mathrm{kDa}$ agrin binds to the structure of the NR1, it bridges serine/threonine kinase to activate residues 896/897 phosphorylation. Therefore, $50 \mathrm{kDa}$ agrin is a necessary condition for GABA neurons' NR1 subunit phosphorylation at the serine residue 896/897 as well as activation of GABA neurons to inhibit the excitation of sensory neurons, and thereby neuropathic pain.

\section{References}

Bennett GJ, Xie YK (1988) A peripheral mononeuropathy in rat that produces disorders of pain sensation like those seen in man. Pain 33:87-107.

Bowe MA, Fallon JR (1995) The role of agrin in synapse formation. Annu Rev Neurosci 18:443-462.

Bowe MA, Deyst KA, Leszyk JD, Fallon JR (1994) Identification and purification of an agrin receptor from Torpedo postsynaptic membranes: a heteromeric complex related to the dystroglycans. Neuron 12:1173-1180.

Campanelli JT, Roberds SL, Campbell KP, Scheller RH (1994) A role for dystrophin-associated glycoproteins and utrophin in agrin-induced AChR clustering. Cell 77:663-674.

Chergui K, Svenningsson P, Greengard P (2005) Physiological role for casein kinase 1 in glutamatergic synaptic transmission. J Neurosci 25:6601-6609.

Cui J-G, Linderoth B, Meyerson BA (1997) Incidence of mononeuropathy in rats is influenced by pre-emptive alteration of spinal excitability. Eur J Pain 1:53-59.

Cui J-G, O'Connor WT, Ungerstedt U, Linderoth B, Meyerson BA (1997) Spinal cord stimulation attenuates augmented dorsal horn release of ex- citatory amino acids in mononeuropathy via a GABAergic mechanism. Pain 73:87-95.

Cui J-G, Zhang X, Zhao YH, Chen C, Bazan N (2006) Allodynia and hyperalgesia suppression by a novel analgesic in experimental neuropathic pain. Biochem Biophys Res Commun 350:358-363.

Dunah AW, Yasuda RP, Luo J, Wang Y, Prybylowski KL, Wolfe BB (1999) Biochemical studies of the structure and function of the N-methyl-Daspartate subtype of glutamate receptors. Mol Neurobiol 19:151-179.

Erichsen HK, Hao JX, Xu XJ, Blackburn-Munro G (2003) A comparison of the antinociceptive effects of voltage-activated $\mathrm{Na}+$ channel blockers in two rat models of neuropathic pain. Eur J Pharmacol 458:275-282.

Fire A, Xu S, Montgomery MK, Kostas SA, Driver SE, Mello CC (1998) Potent and specific genetic interference by double-stranded RNA in Caenorhabditis elegans. Nature 391:806-811.

Furukawa H, Singh SK, Mancusso R, Gouaux E (2005) Subunit arrangement and function in NMDA receptors. Nature 438:185-192.

Gao X, Kim HK, Chung JM, Chung K (2007) Reactive oxygen species (ROS) are involved in enhancement of NMDA-receptor phosphorylation in animal models of pain. Pain 131:262-271.

Gautam M, Noakes PG, Mudd J, Nichol M, Chu GC, Sanes JR, Merlie JP (1995) Failure of postsynaptic specialization to develop at neuromuscular junctions of rapsyn-deficient mice. Nature 377:232-236.

Gazelius B, Cui J-G, Svensson M, Meyerson B, Linderoth B (1996) Photochemically induced ischaemic lesion of the rat sciatic nerve. A novel method providing high incidence of mononeuropathy. Neuroreport 7:2619-2623

Glass DJ, Bowen DC, Stitt TN, Radziejewski C, Bruno J, Ryan TE, Gies DR, Shah S, Mattsson K, Burden SJ, DiStefano PS, Valenzuela DM, DeChiara TM, Yancopoulos GD (1996) Agrin acts via a MuSK receptor complex. Cell 85:513-523.

Gorgels TG, Van Lookeren Campagne M, Oestreicher AB, Gribnau AA, Gispen WH (1989) B-50/GAP43 is localized at the cytoplasmic side of the plasma membrane in developing and adult rat pyramidal tract. J Neurosci 9:3861-3869.

Guo W, Zou S, Guan Y, Ikeda T, Tal M, Dubner R, Ren K (2002) Tyrosine phosphorylation of the NR2B subunit of the NMDA receptor in the spinal cord during the development and maintenance of inflammatory hyperalgesia. J Neurosci 22:6208-6217.

Hildebrand JG, Christensen TA, Harrow ID, Homberg U, Matsumoto SG, Waldrop BR (1992) The roles of local interneurons in the processing of olfactory information in the antennal lobes of the moth Manduca sexta. Acta Biol Hung 43:167-174.

Hilgenberg LG, Smith MA (2004) Agrin signaling in cortical neurons is mediated by a tyrosine kinase-dependent increase in intracellular $\mathrm{Ca} 2+$ that engages both CaMKII and MAPK signal pathways. J Neurobiol 61:289-300.

Hilgenberg LG, Su H, Gu H, O’Dowd DK, Smith MA (2006) Alpha3Na+/ $\mathrm{K}+$-ATPase is a neuronal receptor for agrin. Cell 125:359-369.

Hoch W, Ferns M, Campanelli JT, Hall ZW, Scheller RH (1993) Developmental regulation of highly active alternatively spliced forms of agrin. Neuron 11:479-490.

Hoover CL, Hilgenberg LG, Smith MA (2003) The COOH-terminal domain of agrin signals via a synaptic receptor in central nervous system neurons. J Cell Biol 161:923-932.

Ji RR, Böse CM, Lesuisse C, Qiu D, Huang JC, Zhang Q, Rupp F (1998) Specific agrin isoforms induce cAMP response element binding protein phosphorylation in hippocampal neurons. J Neurosci 18:9695-9702.

Kennedy S, Wang D, Ruvkun G (2004) A conserved siRNA-degrading RNase negatively regulates RNA interference in C. elegans. Nature 427:645-649.

Kim N, Burden SJ (2008) MuSK controls where motor axons grow and form synapses. Nat Neurosci 11:19-27.

Kim N, Stiegler AL, Cameron TO, Hallock PT, Gomez AM, Huang JH, Hubbard SR, Dustin ML, Burden SJ (2008) Lrp4 is a receptor for Agrin and forms a complex with MuSK. Cell 135:334-342.

Liu H, Wang H, Sheng M, Jan LY, Jan YN, Basbaum AI (1994) Evidence for presynaptic N-methyl-D-aspartate autoreceptors in the spinal cord dorsal horn. Proc Natl Acad Sci U S A 91:8383-8387.

Magill C, Reist NE, Fallon JR, Nitkin RM, Wallace BG, McMahan UJ (1987) Agrin. Prog Brain Res 71:391-396.

Mantych KB, Ferreira A (2001) Agrin differentially regulates the rates of 
axonal and dendritic elongation in cultured hippocampal neurons. J Neurosci 21:6802-6809.

Mayer ML, Westbrook GL, Guthrie PB (1984) Voltage-dependent block by Mg2 + of NMDA responses in spinal cord neurones. Nature 309:261-263.

McBain CJ, Fisahn A (2001) Interneurons unbound. Nat Rev Neurosci 2:11-23.

McMahon SB, Lewin GR, Wall PD (1993) Central hyperexcitability triggered by noxious inputs. Curr Opin Neurobiol 3:602-610.

McManus MT, Sharp PA (2002) Gene silencing in mammals by small interfering RNAs. Nat Rev Genet 3:737-747.

O'Connor AB, Dworkin RH (2009) Treatment of neuropathic pain: an overview of recent guidelines. Am J Med 122:S22-S32.

Roh DH, Kim HW, Yoon SY, Seo HS, Kwon YB, Han HJ, Beitz AJ, Lee JH (2008) Intrathecal clonidine suppresses phosphorylation of the $\mathrm{N}$-methyl-D-aspartate receptor NR1 subunit in spinal dorsal horn neurons of rats with neuropathic pain. Anesth Analg 107:693-700.

Rostas JA, Brent VA, Voss K, Errington ML, Bliss TV, Gurd JW (1996) Enhanced tyrosine phosphorylation of the $2 \mathrm{~B}$ subunit of the N-methyl-Daspartate receptor in long-term potentiation. Proc Natl Acad Sci U S A 93:10452-10456.

Ruegg MA, Tsim KW, Horton SE, Kröger S, Escher G, Gensch EM, McMahan UJ (1992) The agrin gene codes for a family of basal lamina proteins that differ in function and distribution. Neuron 8:691-699.

Rupp F, Hoch W, Campanelli JT, Kreiner T, Scheller RH (1992) Agrin and the organization of the neuromuscular junction. Curr Opin Neurobiol 2:88-93.
Salter MW, Kalia LV (2004) Src kinases: a hub for NMDA receptor regulation. Nat Rev Neurosci 5:317-328.

Santiago-Figueroa J, Kuffler DP (2009) Reducing and eliminating neuropathic pain. P R Health Sci J 28:289-300.

Schipke CG, Ohlemeyer C, Matyash M, Nolte C, Kettenmann H, Kirchhoff F (2001) Astrocytes of the mouse neocortex express functional N-methylD-aspartate receptors. FASEB J 15:1270-1272.

Schrattenholz A, Soskic V (2006) NMDA receptors are not alone: dynamic regulation of NMDA receptor structure and function by neuregulins and transient cholesterol-rich membrane domains leads to disease-specific nuances of glutamate-signalling. Curr Top Med Chem 6:663-686.

Skene JH, Jacobson RD, Snipes GJ, McGuire CB, Norden JJ, Freeman JA (1986) A protein induced during nerve growth (GAP-43) is a major component of growth-cone membranes. Science 233:783-786.

Smith MA, Hilgenberg LG (2002) Agrin in the CNS: a protein in search of a function? Neuroreport 13:1485-1495.

Ultenius C, Linderoth B, Meyerson BA, Wallin J (2006) Spinal NMDA receptor phosphorylation correlates with the presence of neuropathic signs following peripheral nerve injury in the rat. Neurosci Lett 399:85-90.

Vaccarino AL, Paul D, Mukherjee PK, Rodríguez de Turco EB, Marcheselli VL, Xu L, Trudell ML, Minguez JM, Matía MP, Sunkel C, Alvarez-Builla J, Bazan NG (2007) Synthesis and in vivo evaluation of non-hepatotoxic acetaminophen analogs. Bioorg Med Chem 15:2206-2215.

Xi D, Keeler B, Zhang W, Houle JD, Gao WJ (2009) NMDA receptor subunit expression in GABAergic interneurons in the prefrontal cortex: application of laser microdissection technique. J Neurosci Methods 176: 172-181. 